\title{
Impact of Degraded RA-3 Fuel Condition on Transportation to and Storage in SRS Basins
}

Savannah River Technology Center

Strategic Materials Technology Department

Materials Technology Section

Publication Date: July 2000

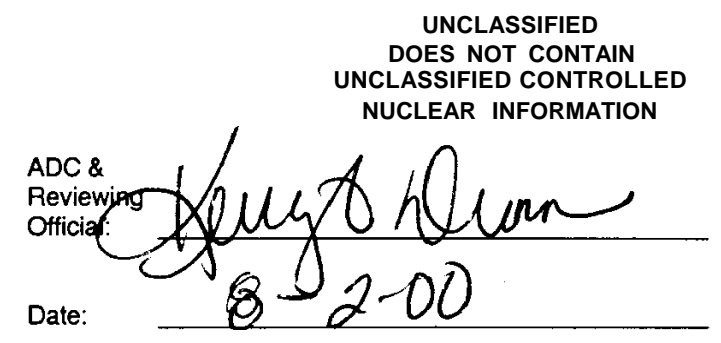

Westinghouse Savannah River Company

Savannah River Site

Aiken, SC 29808

This document was prepared in connection with work done under Contract No. DE-AC09-96SR18500 with the U. S. Department of Energy 
This document was prepared in conjunction with work accomplished under Contract No.

DE-AC09-96SR18500 with the U.S. Department of Energy.

\section{DISCLAIMER}

This report was prepared as an account of work sponsored by an agency of the United States Government. Neither the United States Government nor any agency thereof, nor any of their employees, makes any warranty, express or implied, or assumes any legal liability or responsibility for the accuracy, completeness, or usefulness of any information, apparatus, product or process disclosed, or represents that its use would not infringe privately owned rights. Reference herein to any specific commercial product, process or service by trade name, trademark, manufacturer, or otherwise does not necessarily constitute or imply its endorsement, recommendation, or favoring by the United States Government or any agency thereof. The views and opinions of authors expressed herein do not necessarily state or reflect those of the United States Government or any agency thereof.

This report has been reproduced directly from the best available copy.

Available for sale to the public, in paper, from: U.S. Department of Commerce, National Technical Information Service, 5285 Port Royal Road, Springfield, VA 22161, phone: (800)

553-6847, fax: (703) 605-6900, email: orders@ntis.fedworld.gov online ordering: http://www.ntis.gov/ordering.htm

Available electronically at http://www.doe.gov/bridge

Available for a processing fee to U.S. Department of Energy and its contractors, in paper, from: U.S. Department of Energy, Office of Scientific and Technical Information, P.O. Box 62, Oak Ridge, TN 37831-0062, phone: (865 ) 576-8401, fax: (865) 576-5728, email: reports@ adonis.osti.gov 
WSRC-TR-2000-00152

Page iii of iv

Julv 2000

DOCUMENT: WSRC-TR-2000-00152

TITLE: Impact of Degraded RA-3 Fuel Condition on Transportation to and Storage in SRS Basins

APPROVALS

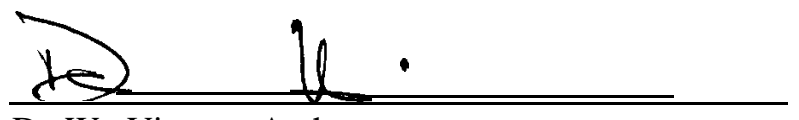

D. W. Vinson, Author

SRTC-MATERIALS TECHNOLOGY SECTION

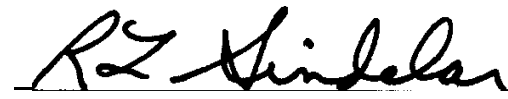

R. L. Sindelar, Author

SRTC-MATERIALS TECHNOLOGY SECTION

SYN been for J.P. Howell

J. P. Howell, Author

SRTC-MATERIALS TECHNOLOGY SECTION

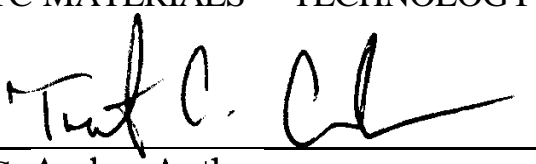

T. C. Andes, Author

SFSD-SNF TECHNOLOGY SECTION

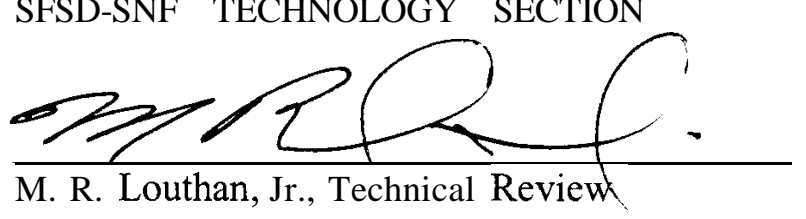

SRTC-MATERIALS TECHNOLOGY SECTION

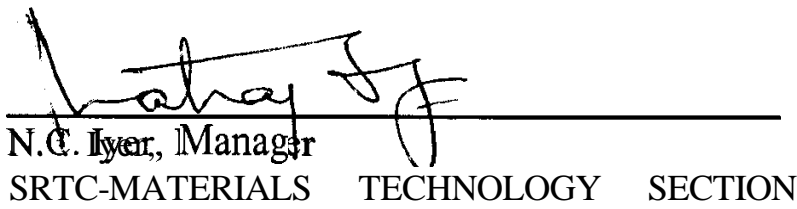

Qu ld W Bully

SFSD-SNF TECHNOLOGY SECTION
Date: $8 / 2 / 00$

Date: $8 / 2 / 00$

Date: $8 / 2 / 00$

Date: $8 / 3 / 00$

Date: $8 / 2 / 00$

Date: $g / 2 / 00$

Date: $8 / 2 / 00$ 


\section{Table of Contents}

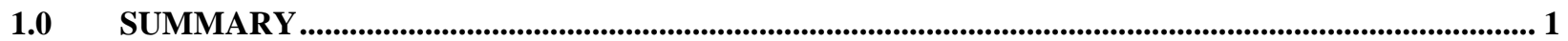

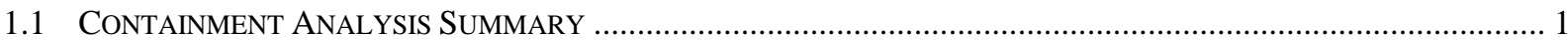

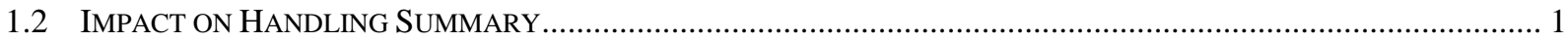

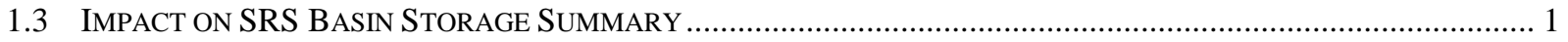

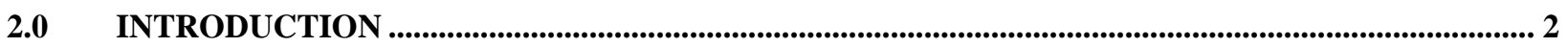

3.0 SUMMARY OF CORROSION AND MECHANICAL DAMAGE ........................................................ 3

4.0 CONTAINMENT ANALYSIS OF RA-3 SNF IN LWT............................................................................. 8

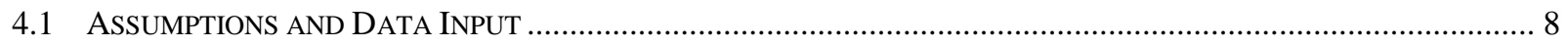

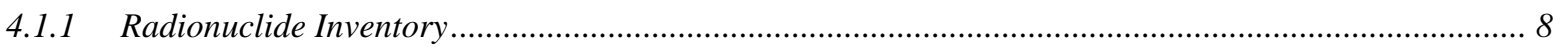

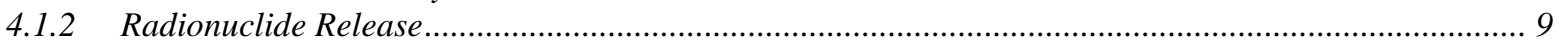

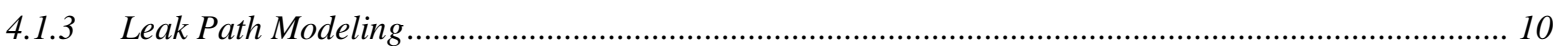

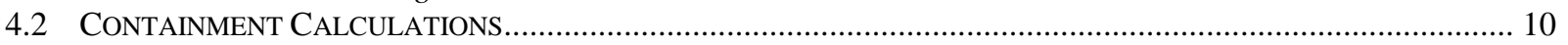

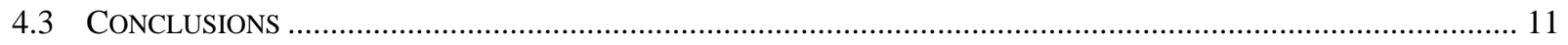

5.0 EFFECT OF RA-3 SPENT NUCLEAR FUEL ON SRS BASIN ACTIVITY.......................................... 12

5.1 MODEL FOR RADIOACTIVITY RELEASE RATE FROM AL-SNF INTO WATER ……........................................ 12

5.2 STEADY-STATE RELEASE OF CESIUM-137 INTO THE BASIN …........................................................... 13

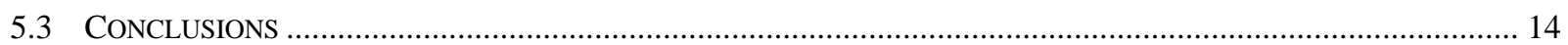

6.0 IMPACT OF DAMAGED FUEL ON HANDLING OPERATIONS ....................................................... 15

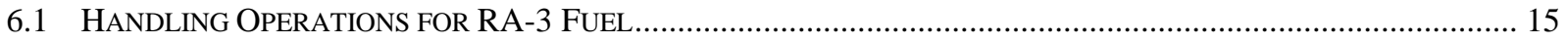

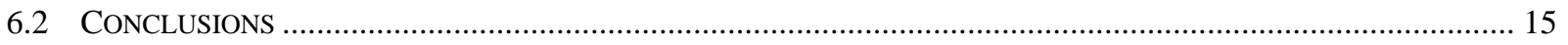

7.0 EVALUATION OF CORROSION DAMAGE DEVELOPMENT ............................................................ 16

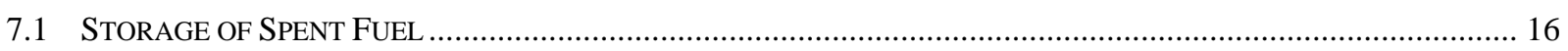

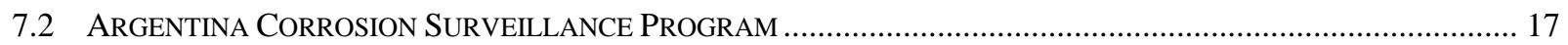

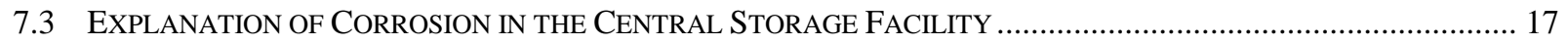

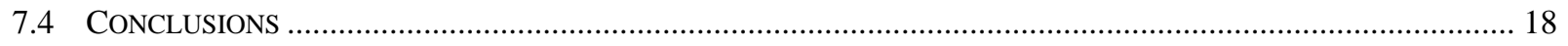

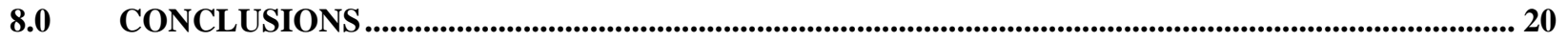

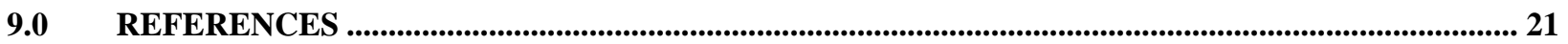

A.0 CONTAINMENT CALCULATIONS FOR RA-3 FUEL SHIPMENT ....................................................A1

A.1 Determination OF $\mathrm{A}_{2}$ VALUES For SourCe Group MiXTURES.......................................................A1

A.2 DETERMINATION OF ACTIVITY DENSITY WITHIN THE CASK FREE VOLUME ............................................

A.2.1 Activity Density of Gases .................................................................................................

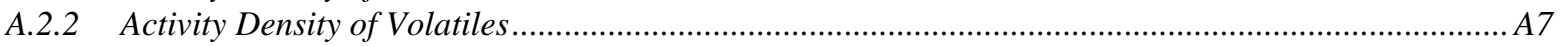

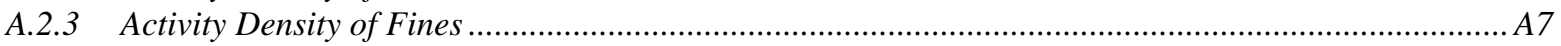

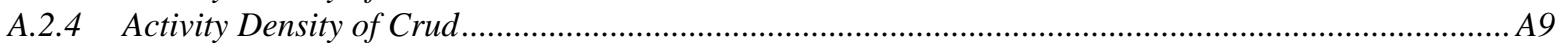

A.3 DETERMining THE Volumetric LEAKAge RATE AT STANDARd Conditions .........................................9

A.3.1 Combining the Sources of Radioactive Material in the Cask Free Volume .........................................A9

A.3.2 Maximum Permissible Release Rate and Maximum Permissible Leakage Rate................................A12

A.3.3 Permissible Leak Rate at Standard Conditions.......................................................................

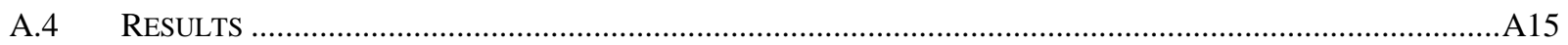

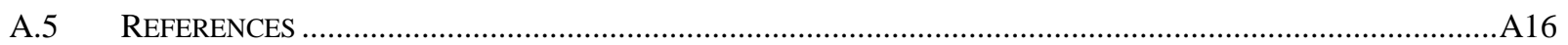




\subsection{SUMMARY}

Aluminum-clad, aluminum-based spent nuclear fuel (Al-SNF) from the RA-3 Research and Test Reactor at the CNEA Ezeiza Atomic Center near Buenos Aires, Argentina, presently in wet storage at the Central Storage Facility (CSF), contains extensive corrosion and mechanical damage. Plans are being developed to return the fuel to the Savannah River Site (SRS) in Fall 2000. The condition of the fuel and its impact on shipping, handling, and basin storage when the fuel is returned to SRS, is discussed in this report.

\subsection{Containment Analysis Summary}

The results from visual examination by SRS personnel in Fall 1999 showed that 134 of the 207 assemblies had exposed fuel meat estimated up to a couple of square centimeters in area. A containment analysis was performed to check if the fuel could be safely shipped in the proposed LWT shipping cask. The containment analysis followed the NRC-approved methodology previously developed by WSRC. A conservative fuel-specific radionuclide inventory for the RA-3 fuel was developed for the analysis. A value for the area of exposed fuel based on the largest area estimated from the visual examination records was applied to each of 42 assemblies (LWT capacity) to determine a "best estimate" case for the maximum exposed fuel area. The results for this "best-estimate" case of $3 \mathrm{~cm}^{2}$, a "conservative" case of $57 \mathrm{~cm}^{2}$, and even a "bounding" case of $2160 \mathrm{~cm}^{2}$ for total exposed fuel area per assembly show that the LWT shipping cask with a test leakage rate of $1.0 \times 10^{-6} \mathrm{~atm} \cdot \mathrm{cm}^{3} / \mathrm{sec}$ would meet the containment requirements in each case and thus may be used to transport the fuel.

\subsection{Impact on Handling Summary}

Several assemblies have deformed plates and there are additional loose plates that are slightly warped. The assemblies will be cropped to approximately $71 \mathrm{~cm}$ at the CSF prior to shipping. The deformed assemblies will be geometrically altered to fit the cell dimensions of the MTR basket by tapping the fuel into a shape. The loose plates may be placed in jackets or cans to limit shifting or banding during transport in the LWT cask. Alternatively, the loose plates would be placed in a stainless steel 2R inner container and then placed in a $6 \mathrm{M}$ container for standard transportation to SRS. The assemblies are destined for conventional storage in the SRS L-basin. The standard tong-type tool would be used for handling and loading into the standard 5-inch diameter bundles for storage in the EBS racks.

\subsection{Impact on SRS Basin Storage Summary}

The effect of directly storing the breached fuel on the activity of the L-basin was evaluated using the expected corrosion rate of the exposed fuel meat. The steady-state activity concentration in the basin would be expected to increase slightly from $5.0 \mathrm{dpm} / \mathrm{ml}$ to approximately $5.2 \mathrm{dpm} / \mathrm{ml}$ with the addition of the RA-3 fuel using the best-estimate for the maximum exposed fuel area for each of the 207 assemblies. These values are well below the operations limit of $200 \mathrm{dpm} / \mathrm{ml}$.

The storage conditions present in the CSF basins promote the continued corrosion of the aluminum fuel. It is fully expected that the storage of the RA-3 fuel in the SRS L-basin will mitigate the corrosion degradation and that the fuel can be safely stored for up to several decades allowing for acceptable basin storage, retrieval, and ultimate disposition alternatives. 


\subsection{INTRODUCTION}

Aluminum-clad spent fuel from the RA-3 Research and Test Reactor at the CNEA Ezeiza Atomic Center near Buenos Aires, Argentina is currently in wet storage at their Central Storage Facility (CSF). This fuel will be returned to the U.S. for storage at the Savannah River Site (SRS). A team of personnel from Westinghouse Savannah River Company (WSRC) performed on-site inspections of this fuel from October 25-November 10, 1999. ${ }^{1}$

The RA-3 fuel is scheduled to be returned to SRS in Fall 2000. The damaged condition has a potential to impact shipping, handling, and storage. This report addresses the impact of the fuel condition with respect to these steps.

Section 3 of this report summarizes the damaged condition of the fuel with photographs and video stills from the inspection. Section 4 summarizes a fuel-specific containment analysis using a conservative radionuclide inventory developed for the RA-3 fuel and conservative assumptions for the breached area of the fuel. The details of the analysis are contained in Appendix A. Section 5 provides an evaluation of the expected radioactivity release from the breached fuel and the increases in steady-state activity of L-basin. Section 6 provides an assessment of the expected impact of the corrosion and mechanical damage on assembly handling. Section 7 contains an evaluation of the causes of the corrosion damage exhibited by the RA-3 fuel. 


\subsection{SUMMARY OF CORROSION AND MECHANICAL DAMAGE}

Visual examinations enhanced by camera magnification using special video imaging and camera equipment were conducted to assess the 207 aluminum-clad fuel and control assemblies. ${ }^{1}$ A majority of the fuel assemblies (198) were inspected by raising the assemblies out of their stainless steel storage tubes and viewing the assemblies with the camera systems. The video systems included an array of three above ground cameras, positioned $120^{\circ}$ apart, to allow viewing of all external assembly surfaces. Three assemblies were missing bails and were partially inspected using a submersible video probe. (These assemblies were inserted into aluminum jackets.) Six assemblies (3 intact and 3 sets of loose plates) were inspected manually, and the inspection was recorded with a digital camera.

The primary objective of the inspections was to characterize the physical condition of the fuel. ${ }^{1}$ The results for each assembly inspected has been recorded on inspection sheets contained in Appendix 1 of Reference 1. The record of visual inspections of the total 207 assemblies are contained on mini digital (DV) tapes and a database documenting the results and a compact disc (CD) photo album of still images were created. Significant corrosion and mechanical damage were recorded.

Corrosion product was highly visible on more than one-half of the assemblies. This corrosion was primarily nodular corrosion nodules on the external surfaces of the fuel and side plates and crevice corrosion between the fuel and side plates. The nodular corrosion resulted from pitting of the aluminum clad resulting, in many cases, in a breach of the clad. A breach of the cladding exposes the aluminumuranium alloy region containing the fissile material or fuel meat. Nominal cladding thickness for the fuel is about $0.039 \mathrm{~cm}(0.015 \mathrm{in})$ for the older RA-3 fuel assembly design and $0.042 \mathrm{~cm}(0.017 \mathrm{in})$ for the newer RA-3 design.

The results of the inspections of each assembly were evaluated and the exposed area of the fuel meat material was estimated. ${ }^{1}$ The estimates do not account for breached cladding that may exist on interior plate surfaces. Some through clad pitting may be present on these interior surfaces, but inspections could not be made in this area. A summary of exposed fuel area, as presented in Reference 1, is provided in Table 1. In generating this table, each fuel assembly has been assigned an Index value ranging from 0 , for no visible localized corrosion, to 5 , for assemblies exhibiting the potential for greater or equal to $1.5 \mathrm{~cm}^{2}$ of exposed fuel meat material or damage that may affect structural stability.

Table 1 Summary of Fuel Assembly Inspections

\begin{tabular}{|l|l|l|}
\hline Number of Fuel Assemblies & Index & Exposed Fuel Meet \\
\hline 67 & 0 & No nodules or general corrosion \\
\hline 24 & 1 & $<0.1 \mathrm{~cm}^{2}$ \\
\hline 48 & 2 & $=0.1 \mathrm{~cm}^{2}$ to $<0.5 \mathrm{~cm}^{2}$ \\
\hline 33 & 3 & $=0.5 \mathrm{~cm}^{2}$ to $<1.0 \mathrm{~cm}^{2}$ \\
\hline 16 & 4 & $=1.0 \mathrm{~cm}^{2}$ to $<1.5 \mathrm{~cm}^{2}$ \\
\hline 19 & 5 & $=1.5 \mathrm{~cm}^{2}$ \\
\hline
\end{tabular}

Notes:

1. In calculating the exposed fuel meat area under a nodule deposit, the area of a nodule was assumed to be the area of exposed fuel meat. Nodules less than 1/8" diameter (general corrosion) were not assumed to penetrate the cladding. The internal fuel plates were assumed to not contain exposed fuel meat.

2. An index of 5 was also ascribed to assemblies with damage potentially significant to their structural integrity. That is, these assemblies may become dissembled if moved roughly. 
Figures 1 through 5 are typical of the corrosion seen on the RA-3 assemblies. Figures 6 and 7 show the extreme in corrosion damage. Exposed fuel meat surface areas were estimated from photographs such as these. On assembly S-133 shown in Figure 1, corrosion nodules can be seen in the active region of the fuel plate. Note that each of the nodules appears to have originated in a scratch in the surface of the fuel clad. Figures 2 and 3 show exposed fuel meat from pitting corrosion. The pits appear to have penetrated the cladding. Figure 2 appears as if corrosion product nodules became dislodged. The pits in Figure 3 appear as if no corrosion nodules formed in the pitting process.

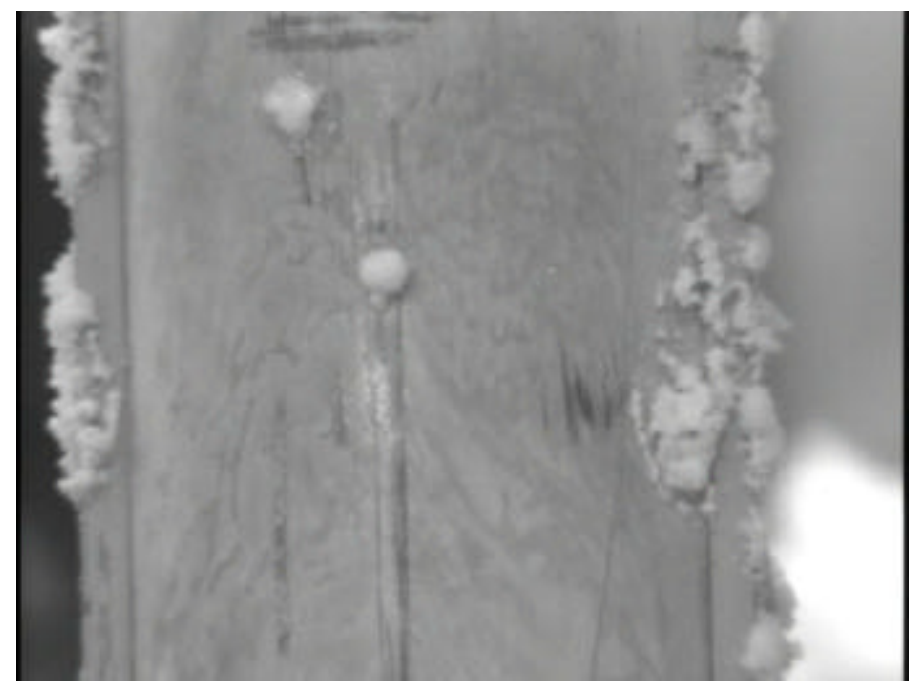

Figure 1 Corrosion nodules in scratches and crevices.



Figure 2 Pits through the clad on MTR fuel plate 


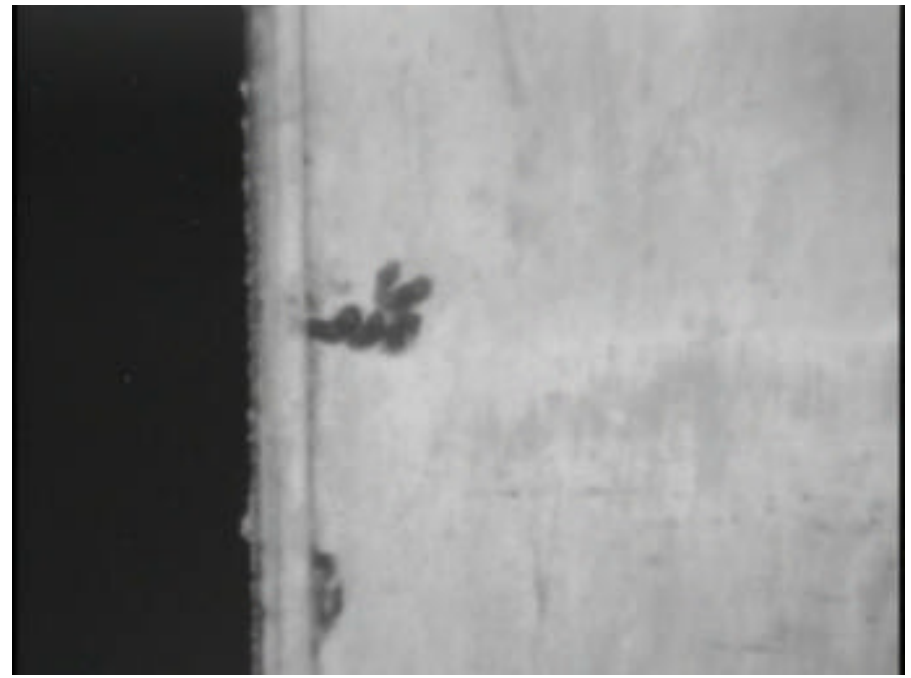

Figure 3 Pits through the clad on MTR fuel plate

Figure 4 shows a case of suspected galvanic corrosion from the use of stainless screws to attach the components of the aluminum-clad fuel assembly together.

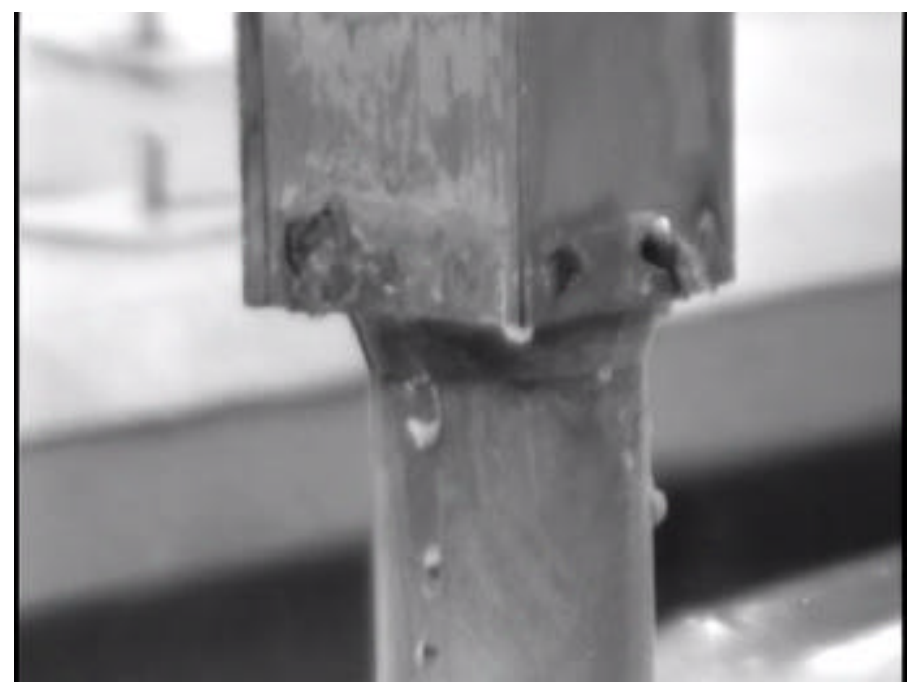

Figure 4 Galvanic corrosion from Stainless steel screws.

Figure 5 shows raised blisters and subsurface tunneling on the aluminum cladding. These blisters likely result from the crevice corrosion initiating in the crevice between the side and fuel plates. Corrosion starts tunneling beneath the clad near the bond line between the clad and fuel meat. This in generally termed filiform corrosion. The formation of corrosion product beneath the cladding surface is suspected to have caused the localized bulging of the cladding. Hydrogen gas liberated during the corrosion reaction may also be trapped beneath the clad. As the corrosion process proceeds beneath the clad, a number of tunnels are formed to give this welt-like surface appearance. 


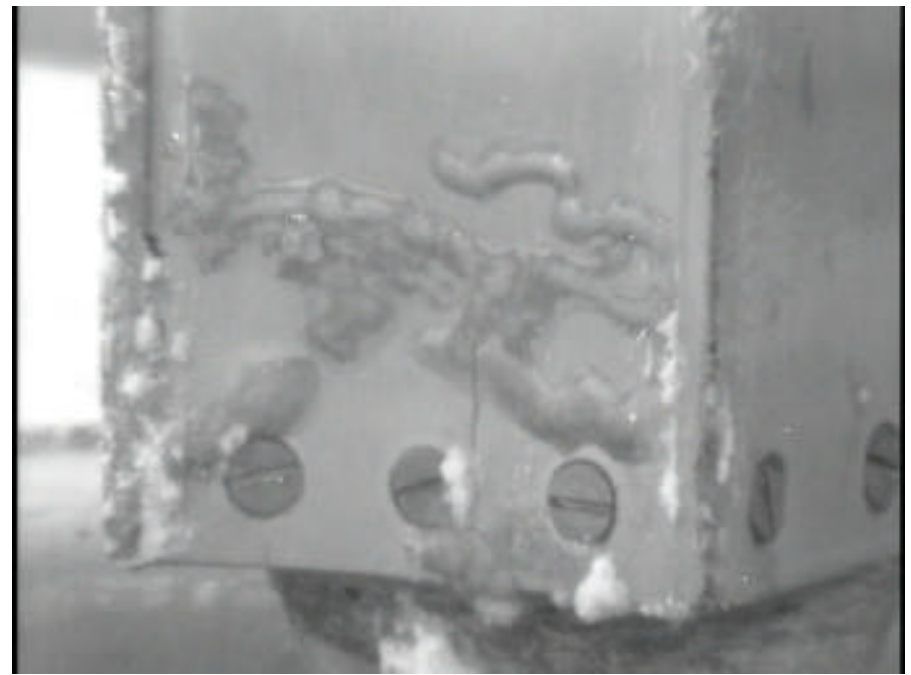

Figure 5 Blisters from tunneling beneath the clad.

Figure 6 shows significant degradation of the nozzle of an MTR assembly. Corrosion of the end of the nozzle was likely driven by a galvanic couple between the aluminum nozzle and the stainless steel bottom plate in the storage tube.

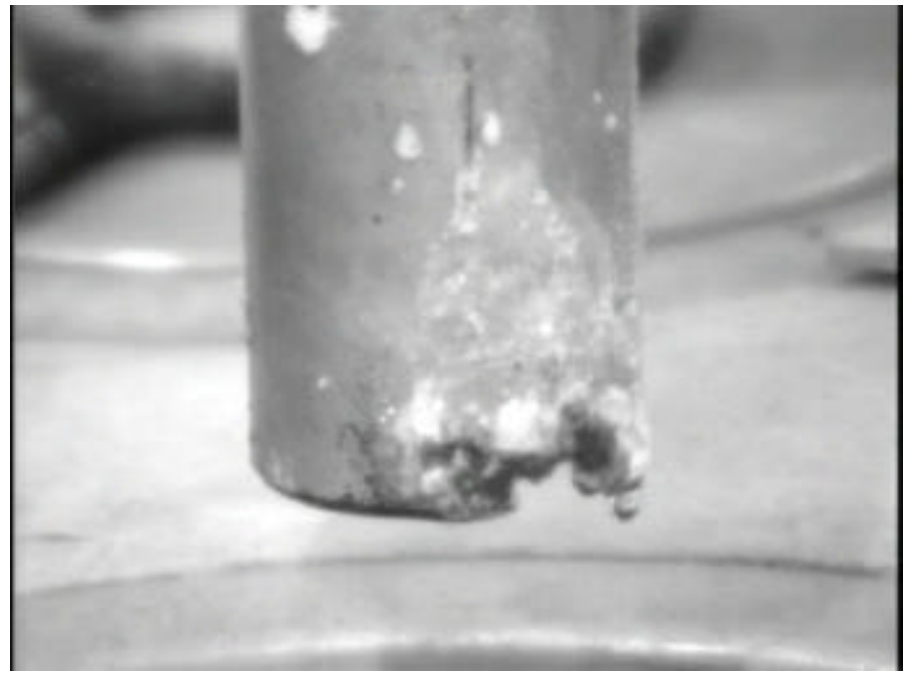

Figure 6 Corrosion on nozzle of fuel.

Figure 7 shows significant damage at the end of an MTR assembly. The damage to this assembly includes corrosion and bending of one outer fuel plate and one side plate. This could be the result of filiform corrosion that caused mechanical loading at the plate end that deformed the plate. Mechanical loading from handling could also have caused this deformation damage. 


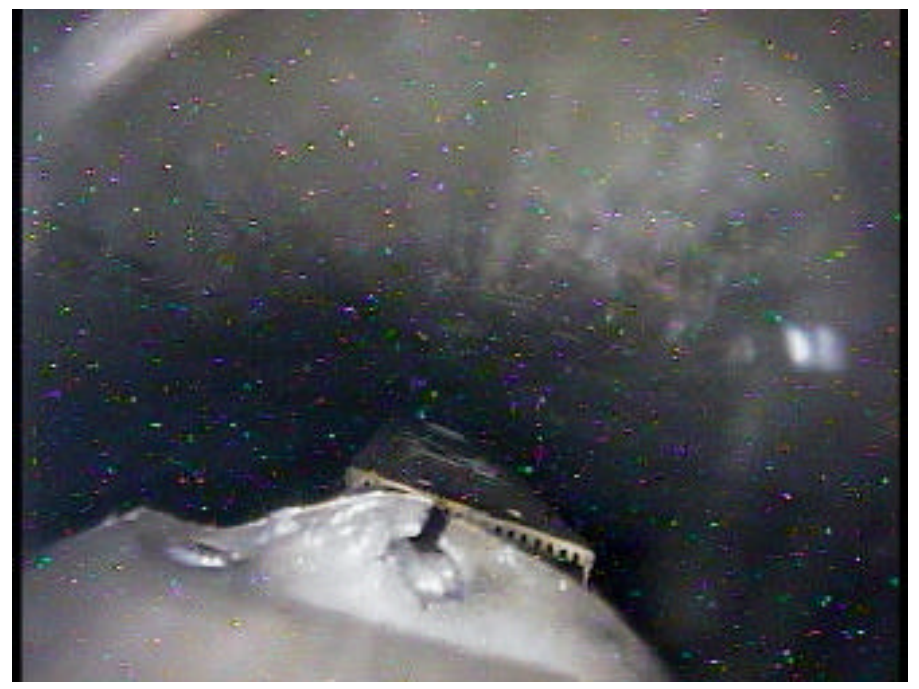

Figure 7 Deformation around bolts of assembly. 


\subsection{CONTAINMENT ANALYSIS OF RA-3 SNF IN LWT}

A discussion of the inputs and results from a fuel and cask specific containment analysis for shipping spent fuel from the RA-3 reactor in Argentina to SRS in the LWT shipping cask is provided in this section. The appendix to this report presents the detailed calculations and results from a computer program developed by WSRC for performing containment analyses for shipping spent nuclear fuel. The program was developed specifically for performing a containment analysis of breached Al-SNF shipments following the methodology previously developed at WSRC and described in Reference 2. WSRC Assumes no responsibility in the application of this report to the licensing of the LWT cask for shipment of RA-3 fuel.

\subsection{Assumptions and Data Input}

The containment analysis of the RA-3 spent nuclear fuel considers three general cases with different assumptions concerning the degree to which the cladding of the RA-3 spent fuel is breached. In the first or "Best-estimate" case, the surface area of exposed fuel meat of the assemblies is derived from records of the visual inspection of the fuel. Consistent with the methodology described in Reference 2, it is assumed that the through clad pitting is limited to the outer fuel plates. The amount of exposed fuel meat per assembly is conservatively assumed equal to $3 \mathrm{~cm}^{3}$, based upon records from the visual inspection of the fuel (see Table 1).

For the second or "Conservative" case, it is conservatively assumed that the corrosion degradation observed on the outer fuel plates represents the maximally degraded fuel plate in the assembly, i.e., the extent of corrosion of the outer plates bounds that of the inner fuel plates. Based upon the records from the visual inspection of the fuel, a conservative value of $3 \mathrm{~cm}^{2}$ is assumed for the amount of exposed fuel meat in a single plate (see Table 1).

In the third or "Bounding" case, extremely conservative values for exposed fuel meat under normal and accident conditions are used. The fuel is taken to be totally de-clad for the accident condition. The values assumed in this case are 38 times higher under normal conditions of transport and 120 times higher under accident conditions than the respective values used in the "Best estimate" case. These values are used to demonstrate the extent of breached cladding that can be safely contained in the LWT for normal and accident transport conditions.

\subsubsection{Radionuclide Inventory}

A radionuclide production/depletion analysis was performed to estimate the fuel-specific isotopics. Determination of the isotopic content of the spent fuel is made through use of a coupled one-dimensional depletion and shielding analysis module, SAS2h, of SCALE4.4. ${ }^{3-4}$ During exposure the assembly cladding is assumed intact regardless of assumption used for containment analysis. It is conservatively assumed that the fuel has been decayed for only 10 years. Additional conservative assumptions used in the calculations concerning the development of the radionuclide inventory were derived from draft Appendix A documents for the RA-3 fuel assemblies ${ }^{5}$ and are provided in Table 2. 
Table 2 Input Assumptions for SAS2h

\begin{tabular}{|l|c|}
\hline \multicolumn{1}{|c|}{ Parameter } & Assumed Value \\
\hline Specific Power [MW/ass] & 0.06 \\
\hline Burn Time [days] & 1204 \\
\hline Cooling Time [years] & 10 \\
\hline Moderator & $\mathrm{D}_{2} \mathrm{O}$ \\
\hline Moderator Temperature [K] & 325 \\
\hline Clad Temperature [K] & 446 \\
\hline Fuel Temperature [K] & 447 \\
\hline Active Meat Thickness [cm] & 0.056 \\
\hline Active Meat Width [cm] & 5.9 \\
\hline Active Meat Length [cm] & 61.5 \\
\hline Number of Plates & 19 \\
\hline Clad Thickness [cm] & 0.042 \\
\hline Pitch [cm] & 0.44 \\
\hline Cladding Material & Aluminum \\
\hline Fuel Material Masses [g/ass] & \\
U-235 & 200.1 \\
U-238 & 22.2 \\
Al & 993.7 \\
\hline
\end{tabular}

\subsubsection{Radionuclide Release}

For the purpose of this analysis, it is assumed that each of the spent RA-3 assemblies exhibits equal amounts of exposed fuel meat surface area. The extent of the exposed fuel meat for the best estimate case has been conservatively estimated from the visual inspection to be $3 \mathrm{~cm}^{2} /$ assembly and $6 \mathrm{~cm}^{2} /$ assembly for the normal and accident conditions of transport, respectively. For the conservative case, it is assumed that $57 \mathrm{~cm}^{2} /$ assembly (i.e., $3 \mathrm{~cm}^{2} /$ plate) and $114 \mathrm{~cm}^{2} /$ assembly (i.e., $6 \mathrm{~cm}^{2} /$ plate) for the normal and accident conditions of transport, respectively. For the bounding case, it is assumed that 2160 $\mathrm{cm}^{2} /$ assembly is exposed for normal transport conditions and that the entire surface of the fuel meat is exposed for accident transport conditions. The value of $2160 \mathrm{~cm}^{2} /$ assembly for the normal conditions of the bounding case represents the maximum exposed surface area that can be exposed without exceeding the required release limit. The assumed fractional release factors of the various radionuclides transported in a Type B package to the cask free volume are summarized in Table 3. These factors are the same as those used in the containment methodology report. ${ }^{2}$ The free volume of the cask was assumed equal to $2.293 \mathrm{E}+5 \mathrm{~cm}^{3}$ when fully loaded with 42 assemblies. 
Table 3 Data Summary of Inputs to Example Release Calculations

\begin{tabular}{|l|c|c|c|}
\hline Parameter & $\begin{array}{c}\text { Best Estimate } \\
\text { Normal/Accident }\end{array}$ & $\begin{array}{c}\text { Conservative Estimate } \\
\text { Normal/Accident }\end{array}$ & $\begin{array}{c}\text { Bounding } \\
\text { Normal/Accident }\end{array}$ \\
\hline $\begin{array}{l}\text { Fraction of Breached Fuel in a Cask, } \mathbf{f}_{\mathbf{b}} \\
\begin{array}{l}\text { This is the fraction of assemblies in a cask } \\
\text { that could release gas, volatiles, and that } \\
\text { result in fuel surface area exposure. }\end{array}\end{array}$ & 1.0 & 1.0 & 1.0 \\
\hline $\begin{array}{l}\text { Amount of Meat Surface Area Exposed, } \\
\text { ESA. }\end{array}$ & $\begin{array}{l}3 \mathrm{~cm}^{2} / \mathrm{ass} / \\
6 \mathrm{~cm}^{2} / \mathrm{ass}\end{array}$ & $\begin{array}{l}57 \mathrm{~cm}^{2} / \mathrm{ass} / \\
114 \mathrm{~cm}^{2} / \mathrm{ass}\end{array}$ & $2160 \mathrm{~cm}^{2} / \mathrm{ass} /$ \\
\hline Fission Gas Release Fraction, $\mathbf{f}_{\mathbf{G}}$ & $0.30 / 1.0$ & $0.30 / 1.0$ & $0.30 / 1.0$ \\
\hline Volatile Release Fraction, $\mathbf{f}_{\mathbf{V}}$ & $1 \mathrm{E}-06$ & $1 \mathrm{E}-06$ & $1 \mathrm{E}-06$ \\
\hline $\begin{array}{l}\text { Fraction of Fuel Meat Corrosion Product } \\
\text { Layer Released due to Spallation, } \mathbf{T}_{\mathbf{F}}\end{array}$ & $0.15 / 1.0$ & $0.15 / 1.0$ & $0.15 / 1.0$ \\
\hline Crud Spallation Fraction, $\mathbf{f}_{\mathbf{C}}$ & $0.15 / 1.0$ & $0.15 / 1.0$ & $0.15 / 1.0$ \\
\hline
\end{tabular}

\subsubsection{Leak Path Modeling}

The volumetric gas leak rate is modeled as a combination of continuum and molecular flow through a single leak path. The leak path is modeled as a smooth, right-circular cylinder with sharp edges. To correlate the maximum permissible leak rates to the leak rate at standard temperature and pressure, the leak rate model is implemented assuming the maximum expected internal cask temperature and the maximum expected pressure drop across the leak path (i.e., the cask boundary) to determine the capillary diameter of the leak path. The calculated diameter is then used in the leak rate model at $298-\mathrm{K}$ with internal and external pressures equal to 1.00 -atm and 0.01 -atm, respectively. The assumptions used in this conversion are provided in the Table 4. Details of these calculations may be found in Section A.3.3 of the appendix to this report.

Table 4 Assumptions Used in Correlation of Maximum Permissible Leakage Rates to Standard Leakage Rates

\begin{tabular}{|l|c|c|}
\hline Parameter & Normal Conditions & Accident Conditions \\
\hline \hline Backfill Gas & $\mathrm{He}$ & $\mathrm{He}$ \\
\hline Capillary Length [cm] & 1.0 & 1.0 \\
\hline Gas Temperature [K] & 474 & 574 \\
\hline Upstream Pressure [atm] & 1.99 & 11.4 \\
\hline Downstream Pressure [atm] & 1.00 & 1.00 \\
\hline
\end{tabular}

\subsection{Containment Calculations}

The containment criterion for Type $\mathrm{B}$ packages requires that a package have a radioactive release rate less than $\mathrm{A}_{2} \times 10^{-6}$ in one hour and $\mathrm{A}_{2}$ per week under normal conditions of transport and for accident conditions, respectively. The parameter $\mathrm{A}_{2}$ has units of curies $(\mathrm{Ci})$ and is isotope dependent. $\mathrm{A}_{2}$ is calculated from the isotopic curie concentration in the fuel as determined through use of the SAS2h module of SCALE4.4.

The following summarizes the results of the containment calculations for the RA-3 spent fuel. The detailed calculations are provided in the appendix to this report. Input for the analysis was provided in the SAR for the $\mathrm{LWT}^{6}$, the Appendix A for the spent fuel ${ }^{5}$, and the documentation of the visual inspection ${ }^{1}$. The analysis followed the methodology developed by WSRC for performing containment analyses for breached Al-SNF. ${ }^{2}$ 
Assuming that the release rate is independent of time, the maximum permissible release rates for normal $\left(\mathrm{R}_{\mathrm{N}}\right)$ and accident $\left(\mathrm{R}_{\mathrm{A}}\right)$ conditions of transport, respectively, can be expressed as follows:

$$
\begin{aligned}
& \mathrm{R}_{\mathrm{N}}=\mathrm{L}_{\mathrm{N}} \mathrm{C}_{\mathrm{N}} \leq \mathrm{A}_{2, \mathrm{~N}} \times 2.78 \times 10^{-10} / \text { second, } \\
& \mathrm{R}_{\mathrm{A}}=\mathrm{L}_{\mathrm{A}} \mathrm{C}_{\mathrm{A}} \leq \mathrm{A}_{2, \mathrm{~A}} \times 1.65 \times 10^{-6} / \text { second, }
\end{aligned}
$$

where:

$R_{i} \quad$ is the release rate for normal $\left(R_{N}\right)$ and accident $\left(R_{A}\right)$ conditions of transport $[C i / s]$,

$\mathrm{L}_{\mathrm{i}}$ is the volumetric gas leakage rate $\left[\mathrm{cm}^{3} / \mathrm{s}\right]$ under normal $\left(\mathrm{L}_{\mathrm{N}}\right)$ and accident $\left(\mathrm{L}_{\mathrm{A}}\right)$ conditions of transport,

$\mathrm{C}_{\mathrm{i}} \quad$ is the curies per unit volume of the radioactive material, "activity density", that passes through the leak path for normal $\left(\mathrm{C}_{\mathrm{N}}\right)$ and accident $\left(\mathrm{C}_{\mathrm{A}}\right)$ conditions of transport $\left[\mathrm{Ci} / \mathrm{cm}^{3}\right]$, and

$A_{2, i}$ is the group $A_{2}$ of the radionuclides available for release under normal $A_{2, N}$ and $A_{2, A}$ accident conditions of transport [Ci].

The group $\mathrm{A}_{2}$ values are determined from the isotopic activity concentration in the fuel along with the assumptions listed in Table 3. These calculations also result in the calculation of the activity density terms in Eqs. 1 \& 2. Using calculated group $\mathrm{A}_{2}$ values in Eqs. 1 \& 2 yields the maximum permissible release rates. Substituting calculated values for activity density and release rate into the same equations yields the volumetric gas leakage rate at the maximum temperature and pressure change across the cask boundary expected during transport. The resulting gas leakage rate is then converted to the maximum leakage rate at standard conditions. The results of these calculations are presented in Table 5.

The calculated standard leakage rates are used to determine whether the loaded cask complies with the containment requirements for shipping spent fuel. These values are compared against the measured cask leakage rate at standard conditions. The measured cask leakage rate must not exceed the calculated maximum leakage rate of the cask at standard conditions to comply with the containment requirements.

\begin{tabular}{|c|c|c|c|c|c|c|}
\hline \multirow[b]{2}{*}{ Parameter } & \multicolumn{2}{|c|}{ Best Estimate } & \multicolumn{2}{|c|}{ Conservative Estimate } & \multicolumn{2}{|c|}{ Bounding Estimate } \\
\hline & $\begin{array}{c}\text { Normal } \\
\text { Transport } \\
\text { Conditions }\end{array}$ & $\begin{array}{c}\text { Accident } \\
\text { Transport } \\
\text { Conditions }\end{array}$ & $\begin{array}{c}\text { Normal } \\
\text { Transport } \\
\text { Conditions }\end{array}$ & $\begin{array}{l}\text { Accident } \\
\text { Transport } \\
\text { Conditions }\end{array}$ & $\begin{array}{c}\text { Normal } \\
\text { Transport } \\
\text { Conditions }\end{array}$ & $\begin{array}{c}\text { Accident } \\
\text { Transport } \\
\text { Conditions }\end{array}$ \\
\hline$\overline{\text { Group } A_{2}[\mathrm{Ci}]}$ & $2.19 \mathrm{E}+02$ & $1.56 \mathrm{E}+02$ & $7.80 \mathrm{E}+1$ & $2.55 \mathrm{E}+1$ & $3.23 \mathrm{E}+0$ & 4.84E-1 \\
\hline $\mathbf{R}[\mathrm{Ci} / \mathrm{s}]$ & $6.10 \mathrm{E}-08$ & $2.57 \mathrm{E}-04$ & $2.17 \mathrm{E}-8$ & $4.21 \mathrm{E}-5$ & $8.98 \mathrm{E}-10$ & $7.99 \mathrm{E}-7$ \\
\hline $\mathrm{C}\left[\mathrm{Ci} / \mathrm{cm}^{3}\right]$ & $6.57 \mathrm{E}-04$ & $2.19 \mathrm{E}-03$ & $6.59 \mathrm{E}-4$ & $2.21 \mathrm{E}-3$ & $7.11 \mathrm{E}-4$ & $4.49 \mathrm{E}-3$ \\
\hline $\mathrm{L}\left[\mathrm{cm}^{3} / \mathrm{sec}\right]$ & $9.28 \mathrm{E}-05$ & 7.17E-01 & $3.29 \mathrm{E}-5$ & $1.90 \mathrm{E}-2$ & $1.26 \mathrm{E}-6$ & $1.78 \mathrm{E}-4$ \\
\hline$\overline{L_{R}\left[\mathrm{std} \mathrm{cm}^{3} / \mathrm{sec}\right]}$ & 8.35E-05 & 1.79E-02 & 2.89E-5 & 2.94E-3 & $1.00 \mathrm{E}-6$ & 2.93E-5 \\
\hline
\end{tabular}

Table 5 Determination of Maximum Leakage Rates $\left[L_{R}\right]$ at Standard Conditions

\subsection{Conclusions}

The results of the containment analysis of the RA-3 spent fuel using conservative assumptions indicate that the spent fuel can be transported in the LWT and maintained within the allowable release rates under normal and accident conditions. The limiting standard leakage rates for both cases correspond to normal conditions of transport. These limiting standard leakage rates indicate that the LWT, with a test leakage rate $1.0 \times 10^{-6} \mathrm{~atm} \bullet \mathrm{cm}^{3} / \mathrm{sec}$, can safely contain the spent fuel from either case during transport. This result is facilitated by low test leakage rate, low fuel burnup, and long cooling time prior to shipment. 


\subsection{EFFECT OF RA-3 SPENT NUCLEAR FUEL ON SRS BASIN ACTIVITY}

Spent nuclear fuel from the RA-3 reactor in Argentina will be stored in L-basin at SRS upon receipt. Some of the fuel assemblies have exposed meat material due to through clad pit penetration. This exposed meat material has the potential to contribute to the activity in the basin through the degradation of the meat and subsequent spallation of the corrosion products formed. This section addresses the potential impact of the introduction of a bounding RA-3 spent fuel assembly on basin activity with respect to the potential release of radioactive ${ }^{137} \mathrm{Cs}$ into the basin water. Past experience at SRS indicates that monitoring ${ }^{137} \mathrm{Cs}$ provides a general trend for overall basin water activity. This is due primarily to the fact that the activity in the basin is predominately driven by ${ }^{137} \mathrm{Cs}$.

The bounding assembly is a hypothetical construct of an assembly with a burnup of $72.24 \mathrm{MWd}(\sim 45 \%)$, a cooling time of 10 years, and $3 \mathrm{~cm}^{2} /$ assembly of exposed fuel meat material. The burnup is chosen based upon the highest burnup provided in the Appendix A's for the spent fuel. ${ }^{5}$ The minimum cooling time provided in the Appendix A's is approximately 12 years, and a conservative value of 10 years has been evaluated. The value for the surface area of exposed fuel meat is derived from the visual inspection of the individual fuel assemblies in Argentina and is consistent with that used in the containment calculations.

The methodology to evaluate the effect of breached fuel on basin activity was previously established in Reference 7. Sections 5.1 and 5.2 summarize this methodology and provide the calculations to estimate the effect of the RA-3 fuel on the L-basin steady state activity level.

\subsection{Model for Radioactivity Release Rate from Al-SNF into Water}

Overall basin activity is gauged on the concentration of ${ }^{137} \mathrm{Cs}$ in the basin water as determined by chemical analysis of basin water samples. Therefore, modeling radiation release rates from Al-SNF into the basin water concentrates on the release rate of ${ }^{137} \mathrm{Cs}$. In general, the release of radioactivity from AlSNF with breached cladding into water is dependent on several factors:

- $\quad$ area of exposed fuel

- environment (temperature and quality of the water);

- radioisotope content of fuel (enrichment, burn-up, and decay time);

- fuel meat material (post-irradiation composition and microstructure); and

- clad material

At the low temperatures typical of basin storage (approximately room temperature), corrosion is the primary mechanism whereby species from the fuel core are released into the water. That is, diffusion transport of species from regions in the fuel core to the exposed fuel surface and direct release is not significant.

The radionuclides are assumed to be fully soluble and free to disperse into the water, and not bound in the corrosion product. A simple model to estimate the release from fuel core has been developed by considering general corrosion of the fuel core region directly exposed to the environment. ${ }^{7}$ The release model is given by:

$$
\mathrm{R}=\mathrm{A} \times \mathrm{B} \times \mathrm{C}
$$


where:

$\mathrm{R} \quad$ is the ${ }^{137} \mathrm{Cs}$ release rate $[\mathrm{Ci} / \mathrm{hr}]$;

A is the ${ }^{137} \mathrm{Cs}$ activity density in the fuel meat material at the decay time of interest $\left[\mathrm{Ci} / \mathrm{cm}^{3}\right]$;

B is the area of fuel exposed to the environment (area of breach) $\left[\mathrm{cm}^{2}\right]$; and

$\mathrm{C}$ is the general corrosion rate of the fuel core material in the environment of exposure $[\mathrm{cm} / \mathrm{hr}]$.

A single bounding fuel assembly contains approximately 159 curies of ${ }^{137} \mathrm{Cs}$ (see Table A.3). The fuel meat volume is provided in Section A.2.3 and is equal to $386 \mathrm{~cm}^{3} /$ assembly. Therefore the ${ }^{137} \mathrm{Cs}$ activity density in the meat region (A) is $0.412 \mathrm{Ci} / \mathrm{cm}^{3}$. B represents the total area of exposed fuel meat for all 207 RA-3 assemblies. It is determined by using the data presented in Table 1 and is equal to the sum of the product of the number of assemblies in each category (Column 1) and the upper bound of the estimated exposed meat surface area (from Column 3). For fuel assemblies with an index of 5, an upper bound of $3 \mathrm{~cm}^{2}$ is assumed. The resulting exposed meat surface area is $140.4 \mathrm{~cm}^{2}$, and $\mathrm{C}$ is assumed equal to $5.808 \mathrm{E}-8 \mathrm{~cm} / \mathrm{hr}(5 \mathrm{E}-4 \mathrm{~cm} / \mathrm{yr})$, consistent with containment calculations. The ${ }^{137} \mathrm{Cs}$ release rate into the basin from all RA-3 spent fuel assemblies is calculated to be approximately $3.36 \mu \mathrm{Ci} / \mathrm{hr}$. The total calculated release rate from a single Index 5 assembly is equal to $0.07 \mu \mathrm{Ci} / \mathrm{hr}$, which complies with the failed fuel criteria that limits the release rate below $20.7 \mu \mathrm{Ci} / \mathrm{hr}$ from any one assembly. ${ }^{8}$

\subsection{Steady-State Release of Cesium-137 into the Basin}

The activity concentration of the basin is directly related to the pumping rate through the deionizers and the release rate of ${ }^{137} \mathrm{Cs}$ from the existing basin sources and from the RA-3 fuel meat material exposed by the through clad penetration. The long-term steady-state activity concentration in the basin will be from these sources. The increase in steady-state ${ }^{137}$ Cs activity due to the addition of all 207 RA-3 spent fuel assemblies is estimated by the following.

$$
\mathrm{Q} \cdot \mathrm{C}=\mathrm{A} \cdot \mathrm{V}
$$

where:

Q is the flow rate through the system [gal/day],

C is the steady-state ${ }^{137} \mathrm{Cs}$ activity of the water $[\mathrm{dpm} / \mathrm{ml}]$,

A is the ${ }^{137} \mathrm{Cs}$ release rate to the water $[\mathrm{dpm} / \mathrm{ml} / \mathrm{day}$, and

$\mathrm{V}$ is the basin volume [gal].

This equation is used to first determine the steady-state activity release rate to the basin before adding the RA-3 fuel. The value of Q is assumed to be $288,000 \mathrm{gal} / \mathrm{day}$, consistent with the value used in Reference 7. The basin volume is 3,500,000 gallons ${ }^{9}$, and the steady-state activity of the basin water is assumed equal to $5.0 \mathrm{dpm} / \mathrm{ml}$. Using the previous equation, it is calculated that the steady-state release rate prior to the addition of the RA-3 fuel assemblies is $0.411 \mathrm{dpm} / \mathrm{ml} / \mathrm{day}$. An additional $0.014 \mathrm{dpm} / \mathrm{ml} / \mathrm{day}$ $(3.36 \mu \mathrm{Ci} / \mathrm{hr}){ }^{137} \mathrm{Cs}$ activity would be released from the RA-3 assemblies. Hence, the total release rate, including existing basin sources and that due to the addition of all 207 RA-3 spent fuel assemblies, is $0.42 \mathrm{dpm} / \mathrm{ml} /$ day. This new value (A) is used in the above equation to determine the value of $\mathrm{C}$. The result is that the introduction of the RA-3 assemblies will cause the steady-state activity concentration in the basin to increase from $5.0 \mathrm{dpm} / \mathrm{ml}$ to $5.2 \mathrm{dpm} / \mathrm{ml}$ compared to the basin operation limit of $200 \mathrm{dpm} / \mathrm{ml}$ for ${ }^{137} \mathrm{Cs}$ activity. These calculations indicate that the addition of the RA-3 spent fuel assemblies will have little impact on the steady-state activity concentration in the basin. 


\subsection{Conclusions}

The calculations presented above indicate that the introduction of all 207 RA-3 fuel assemblies, with a combined total exposed meat surface area of $140.4 \mathrm{~cm}^{2}$, into L-Basin would result in a $0.2 \mathrm{dpm} / \mathrm{ml}$ increase in the steady-state ${ }^{137} \mathrm{Cs}$ activity in the basin, resulting in a steady-state value of $5.2 \mathrm{dpm} / \mathrm{ml}$. This value is well below the basin operations limit of $200 \mathrm{dpm} / \mathrm{ml}$ for ${ }^{137} \mathrm{Cs}$ activity. Based upon these calculations and assumptions, it is determined that the addition of the RA-3 spent fuel will have negligible impact on safe basin operations.

Using the estimated rate of $5 \mu \mathrm{m} / \mathrm{year}$ for the corrosion rate of both the aluminum cladding and exposed fuel meat in the SRS basin water chemistry, insignificant damage or reconfiguration of the fuel would occur under a period of extended storage (e.g., 20 years). Therefore, the parameters are assumed to be a constant over the storage period. 


\subsection{IMPACT OF DAMAGED FUEL ON HANDLING OPERATIONS}

This section provides an assessment of the handling steps at CSF and SRS needed to load the fuel into the shipping cask and store the fuel in SRS bundled storage.

\subsection{Handling Operations for RA-3 Fuel}

The RA-3 fuel assemblies are to be shipped to SRS in the LWT transport and shipping package. This package has the capacity to carry 42 standard MTR-type assemblies in its MTR basket. The cell dimensions of the basket is $8.7 \times 8.7 \times 72.77 \mathrm{~cm}$, while the RA-3 fuel assembly is $8.4 \times 7.6 \times 88 \mathrm{~cm}^{5-6}$ Loose plates will be placed in jackets or cans to limit shifting during transport in the LWT. The length of the RA-3 fuel assemblies will be cropped at the CSF to about $71 \mathrm{~cm}$. For some assemblies, the cropping process will require cutting through regions deformed by corrosion damage (see Figure 4 and Figure 5). Further, these deformed assemblies may prove problematic when trying to fit the 8.7 x $8.7 \mathrm{~cm}$ basket cell. In that case, the deformed areas of the assemblies will be physically altered to fit the basket. Likewise, assemblies with plates bent by handling and loose plates that are slightly warped will be manually deformed to fit the basket cell and can, respectively. The cropped assemblies will then be loaded into the cask basket using a long-handled tong-type tool.

Upon receipt at SRS L-Basin, the assemblies will be unloaded with a similar tong-type tool and loaded into 5-inch diameter L-bundles and stored in L-basin EBS racks prior to disposition. It is expected that the unloaded cask will contain debris that will require disposal. This debris is expected to be comprised primarily of aluminum-oxide that may spall off during shipping. Some small quantities of fissile species and fission products are expected to present in the debris, but should not inhibit cask cleanup. Characterization of debris from other damaged fuel recently received at SRS provides the basis for this estimate. $^{10}$

\subsection{Conclusions}

Based upon the visual inspection of the RA-3 spent fuel at Ezeiza, it is expected that the fuel assemblies have not undergone sufficient corrosion degradation or damage as to significantly reduce the structural integrity of the fuel assemblies. The assemblies are expected to maintain sufficient integrity to allow the necessary handling/cropping required to safely assemblies to SRS. Based on the assessment of corrosion in extended basin storage (e.g., 20 years) in the previous section, no further decrease in assembly structural integrity is expected. Therefore, the RA-3 spent fuel assemblies should not require special handling, excepting deforming plates/assemblies to within basket tolerances. 


\subsection{EVALUATION OF CORROSION DAMAGE DEVELOPMENT}

This section provides an evaluation of the causes of corrosion damage exhibited by the RA-3 spent fuel assemblies.

\subsection{Storage of Spent Fuel}

There are 166 standard aluminum-clad MTR spent fuel assemblies and 41 control assemblies stored in the CSF. The fuel has been in the wet storage facility for 10 to 30 years. There are two storage areas, each area with six rows of in-ground storage tubes. There are 198 storage tubes with each tube capable of holding 2 standard assemblies or 1 control assembly. There are 16-17 tubes on each row and the individual rows can be valved together to share the same water environment or they can be individually isolated. The rows are designed such that the water storage environment can, and does, vary from row to row. The storage tubes are built from stainless steel with lead filled stainless steel shield plugs.

The tubes are filled with water that has not been deionized or filtered in over 10 years. The water is not circulated and remains stagnant. The source of the original water is not known. The water level is monitored and water is added when the level is too low to cover the assemblies. A water level of about $15 \mathrm{~cm}$ above the top of the assemblies is desired for shielding.

The water chemistry of two of the empty storage channels that contain no fuel has been monitored in the IAEA corrosion surveillance tests reported in a recent progress report. ${ }^{11}$ This chemistry is shown in Table 6. Values of gamma activity in other channels range up to $120,000 \mathrm{~Bq} / \mathrm{l}$.

Table 6 Water Chemistry in Channels 1 and 113

\begin{tabular}{|l|c|c|c|c|c|c|}
\hline \multirow{2}{*}{ Parameter } & \multirow{2}{*}{ Initial } & \multicolumn{3}{|c|}{ Channel 1 } & \multicolumn{2}{c|}{ Channel 113 } \\
\cline { 3 - 6 } & & $\mathbf{5 / 2 8 / 9 8}$ & $\mathbf{7 / 1 / 9 8}$ & $\mathbf{7 / 2 8 / 9 8}$ & $\mathbf{5 / 2 8 / 9 8}$ & $\mathbf{7 / 1 / 9 8}$ \\
\hline pH & $7.5\left(22^{\circ} \mathrm{C}\right)$ & 7.5 & 7.5 & 7.5 & 8 & 8 \\
\hline Conductivity $(\boldsymbol{\mu S} / \mathbf{c m})$ & 74 & 79 & 82 & 81 & 169 & 160 \\
\hline Chloride ion (ppm) & 14.8 & 15.6 & 14.8 & 16.0 & 3.2 & 3.6 \\
\hline Nitrate ion (ppm) & ND* & ND & ND & ND & ND & ND \\
\hline Nitrite ion (ppm) & ND & ND & ND & ND & ND & ND \\
\hline Sulfate ion (ppm) & ND & ND & ND & ND & ND & ND \\
\hline Cu ions (ppm) & ND & ND & ND & ND & ND & ND \\
\hline Ag ion (ppm) & ND & ND & ND & ND & ND & ND \\
\hline Dissolved solids (ppm) & 8.8 & 59 & 68 & 74 & 106 & 116 \\
\hline Temperature ( $\left.{ }^{\circ} \mathbf{C}\right)$ & $15-20$ & $15-20$ & $15-20$ & $15-20$ & $15-20$ & $15-20$ \\
\hline Gamma Activity, Cs Bq/I & $9000^{*}$ & ND & ND & ND & ND & ND \\
\hline Co activity Bq// & 58 & ND & ND & ND & ND & ND \\
\hline
\end{tabular}

*Concentration Not Determined (ND).

As can be seen in the table, there is a large variation in chemistry in the two different tubes or channels. With water conductivity ranging from $80-169 \mu \mathrm{S} / \mathrm{cm}$ and chloride ion contents from 4-16 ppm, this water would be expected to be aggressive to corrosion of aluminum alloys especially if there is little or no protective oxide film of boehmite. ${ }^{12,13}$ In comparison, the highest recorded conductivity and chloride ion contest for the SRS basins was about $178 \mu \mathrm{S} / \mathrm{cm}$ and from $15-25 \mathrm{ppm}$, respectively. The SRS water was periodically deionized and circulated at the time, whereas the CSF storage tubes contain stagnant, untreated water. 


\subsection{Argentina Corrosion Surveillance Program}

The IAEA initiated a Coordinated Research Program (CRP) in 1996 with ten countries around the world storing research and test reactor aluminum-clad spent fuel. As a participant in this CRP on "Corrosion of Research Reactor Aluminum-Clad Spent Fuel in Wet Storage," Dr. Roberto Haddad, as Principal Investigator, set-up his initial corrosion experiments using a standard corrosion coupon rack as provided by the IAEA. ${ }^{11}$ This rack contained the standard aluminum alloys contained in most of the MTR type fuel (1100, 6061, 6063). Galvanic and crevice corrosion specimens were used along with standard wafer specimens. In addition one rack was made up with aluminum alloys used in the RA-3 fuels. All total, 126 corrosion coupons were tested. His experiments were carried out in storage channels \#46 and \#113 in the CSF. These tubes contained no fuel, but the water chemistry was thought to be typical of the chemistry in the tubes storing fuel.

The first rack of coupons was removed from tube \#46 after 60 days because of visible signs of corrosion. The crevice specimens were stuck together from corrosion. The coupons were cleaned and decontaminated prior to doing metallography. Examination of these coupons showed significant pitting corrosion characterized by white corrosion nodules on surfaces exposed to the water and pitting in crevices. Many of the pits on the open surfaces were associated with dust-like particles thought to be iron from carbon steel corrosion products. The particles were more prevalent on the top of the coupons where the particles settled.

\subsection{Explanation of Corrosion in the Central Storage Facility}

The corrosion seen on the irradiated aluminum-clad assemblies in the Central Storage Facility is classical for aluminum alloys and is caused primarily by poor water chemistry. The water in the individual storage tubes is stagnant and has not been deionized for more than 10 years. The three mechanisms of corrosion clearly evident on the fuel assemblies are pitting, crevice, and galvanic corrosion. The major factors believed to be responsible for the corrosion of the aluminum-clad fuels are:

- High water conductivity

- Aggressive impurity ions

- Deposition of Fe particles from sludge

- Galvanic couples between stainless/aluminum

- Crevices between fuel/side plates

- Scratches and imperfections in the protective oxide coating

- Stagnant water

With the corrosion processes being electrochemical, the increased conductivity of the basin water, or electrolyte, plays a key role in the flow of electrons and electrical current. Very pure deionized water with a low conductivity, e.g. $<10 \mu \mathrm{S} / \mathrm{cm}$, offers resistance to the flow of current. The amount of metal removed in a corrosion process is directly related to the flow of current. Water continuously deionized to a conductivity near $1 \mu \mathrm{S} / \mathrm{cm}$ has been reported to store aluminum-clad fuel for more that 25 years without corrosion. ${ }^{14}$

Pitting is commonly produced in aluminum by the halide ions, of which the most frequently encountered is the chloride ion. The rate of corrosion and tendency for pitting is controlled by the protective oxide film formed on the aluminum surfaces. ${ }^{13}$ The corrosiveness of the water in the storage tube is influenced to a large extent by the ability of the impurity ions to penetrate the oxide film to attack the bare metal. Other impurities like sulfate and nitrate play a role in dissolution or thinning of the protective oxide film making it easier for the aggressive ion to attack the metal. 
The galvanic couple between stainless steel and aluminum can accelerate the corrosion processes. Coupon tests in the CSF storage tubes demonstrated this phenomena in crevice samples and this has also been shown in SRS corrosion surveillance tests as well as on actual fuel on stainless steel hangers. The flow of current between the two dissimilar metals is due to the potential difference of the two metals. During the coupling, the corrosion of the less corrosion-resistant metal (aluminum) increases and the surface becomes anodic, while corrosion of the more corrosion-resistant metal (stainless steel) decreases and the surface becomes cathodic. There is some evidence for galvanic corrosion on the RA-3 fuel where the stainless steel screws are in contact with the aluminum fuel at the bottom of the MTR element and for those assemblies that sit on the stainless bottom of the storage tubes. However, corrosion at the stainless steel screw/plate juncture was not evident on most of the assemblies.

Corrosion at the juncture of the fuel/side plates is responsible for a significant amount of corrosion of this fuel. Much of the corrosion appears to start in the crevice and, in a few instances, tunnel out into the fuel meat. Metals like aluminum, which depend on oxide films or passive layers for corrosion resistance are particularly susceptible to crevice corrosion.

Additional factors are likely playing some role in the significant corrosion seen on the fuel. From the surveillance coupons in the CSF storage tubes, Haddad shows evidence for iron particles associated with pitting on the upper surfaces of the coupons. ${ }^{11}$ These particles are able to deposit themselves on the surfaces of the aluminum setting up a cathodic/anodic reaction. This reaction can cause pitting of the aluminum.

Scratches in the protective oxide coating on the assemblies can be clearly seen in the photographs and the digital video taken during the fuel inspections. Corrosion nodules are seen initiating in the scratches.

Some passivation takes place in these scratched areas, but the oxide coating formed there is formed at low water temperatures and is not as protective as the high temperature oxide formed during irradiation. In addition, the untreated water in the storage tubes is not circulated. Stagnant, poor quality water promotes corrosion.

Corrosion of the UAl fuel meat, once the clad is penetrated, will be similar to that of the aluminum alloy cladding material. Linear Polarization measurements made on fresh surfaces without the protective high temperature oxide of irradiated spent fuel give a rate of about 0.2 mils per year for both aluminum alloy and UAl. ${ }^{15}$ The RA-3 fuel shows significant pitting, but only a small percentage of the fuel meat is pitted through the clad and exposed to the water in the storage tubes.

Continued storage of the Argentina fuel in the existing poor quality water environment prior to shipment back to the U. S. will result in continued corrosion of the fuel elements. Weak spots in the protective oxide would be attacked quickly by the aggressive ions in the water environment. Many of these weak locations already have established pits developed during the 10 to 30 year storage times. New pits may be initiated with continued storage times, but the initiation rate would likely be slower. Continued consumption of the fuel meat under the corrosion nodule would be expected in the poor quality water.

Corrosion of the RA-3 fuel assemblies has been characterized as shown in Table 1 with 19 of the total 207 assemblies exhibiting the potential for greater or equal to $1.5 \mathrm{~cm}^{2}$ of exposed fuel meat material or damage to a degree that may impact structural stability. Most of the visible corrosion on the fuel plates is isolated pits, but in some cases a few pits join together to form bigger pits.

\subsection{Conclusions}

Inspections of RA-3 spent fuel in the CSF have shown about $2 / 3$ of the aluminum-clad fuel assemblies have significant corrosion. This corrosion has resulted, in many cases, in pits penetrating the aluminum 
clad into the fuel meat region. Pitting, crevice, and galvanic corrosion are primarily responsible for the damage to the fuel assemblies. The corrosion is caused by the long-term storage in extremely poor quality water. The major factors responsible for this corrosion are high water conductivity, high concentrations of chloride ions, deposition of iron particles on the fuel, and galvanic couples between stainless and aluminum in the storage tubes. The corrosion seen on the assemblies is advanced but consistent with that previously observed in other Al-SNF in poor water conditions.

Continued storage of this fuel in this poor quality water will result in some additional damage to the assemblies. The corrosion rate of UAl fuel is slow and similar to aluminum alloys. Weak spots in the protective oxide coating on the surface of the fuel plates are attacked quickly by the chlorides and other aggressive ions in the water. Many of these weak areas have already been attacked and established pits during the previous $10-30$ years of storage. New pits may continue to be initiated, but the initiation rate will be slower. 


\subsection{CONCLUSIONS}

The results of the containment analysis of the RA-3 spent fuel using conservative assumptions indicate that the spent fuel can be transported in the LWT and maintained within the allowable release rates under normal and accident conditions. The limiting standard leakage rates for both cases correspond to normal conditions of transport. These limiting standard leakage rates indicate that the LWT, with a test leakage rate $1.0 \times 10^{-6} \mathrm{~atm} \cdot \mathrm{cm}^{3} / \mathrm{sec}$, can safely contain the spent fuel from either case during transport. This result is facilitated by low test leakage rate, low fuel burnup, and long cooling time prior to shipment.

The calculations of expected radionuclide release to SRS basin water indicate that the introduction of all 207 RA-3 fuel assemblies, with a combined total exposed meat surface area of $140.4 \mathrm{~cm}^{2}$, into L-Basin would result in a $0.2 \mathrm{dpm} / \mathrm{ml}$ increase in the steady-state ${ }^{137} \mathrm{Cs}$ activity in the basin, resulting in a steadystate value of $5.2 \mathrm{dpm} / \mathrm{ml}$. This value is well below the basin operations limit of $200 \mathrm{dpm} / \mathrm{ml}$ for ${ }^{137} \mathrm{Cs}$ activity. Based upon these calculations and assumptions, it is determined that the addition of the RA-3 spent fuel will have negligible impact on safe basin operations.

Using the estimated rate of $5 \mu \mathrm{m} /$ year for the corrosion rate of both the aluminum cladding and exposed fuel meat in the SRS basin water chemistry, insignificant damage or reconfiguration of the fuel would occur under a period of extended storage (e.g., 20 years). Therefore, the parameters are assumed to be a constant over the storage period.

Based upon the visual inspection of the RA-3 spent fuel at Ezeiza, it is expected that the fuel assemblies have not undergone sufficient corrosion degradation or damage as to significantly reduce the structural integrity of the fuel assemblies. The assemblies are expected to maintian sufficient integrity to allow the necessary handling/cropping required to safely assemblies to SRS. Based on the assessment of corrosion in extended basin storage (e.g., 20 years) in the previous section, no further decrease in assembly structural integrity is expected. Therefore, the RA-3 spent fuel assemblies should not require special handling, excepting deforming plates/assemblies to within basket tolerances.

Inspections of RA-3 spent fuel in the CSF have shown about $2 / 3$ of the aluminum-clad fuel assemblies have significant corrosion. This corrosion has resulted, in many cases, in pits penetrating the aluminum clad into the fuel meat region. Pitting, crevice, and galvanic corrosion are primarily responsible for the damage to the fuel assemblies. The corrosion is caused by the long-term storage in extremely poor quality water. The major factors responsible for this corrosion are high water conductivity, high concentrations of chloride ions, deposition of iron particles on the fuel, and galvanic couples between stainless and aluminum in the storage tubes. The corrosion seen on the assemblies is advanced but consistent with that previously observed in other Al-SNF in poor water conditions.

Continued storage of this fuel in this poor quality water will result in some additional damage to the assemblies. The corrosion rate of UAl fuel is slow and similar to aluminum alloys. Weak spots in the protective oxide coating on the surface of the fuel plates are attacked quickly by the chlorides and other aggressive ions in the water. Many of these weak areas have already been attacked and established pits during the previous 10-30 years of storage. New pits may continue to be initiated, but the initiation rate will be slower. 


\subsection{REFERENCES}

1 Andes, T. C., Castle, R. B., Large, W. S., Robinson, C. W., and Sindelar, R. L., “Inspection of RA-3 Spent Fuel Assemblies at CNEA's Central Atomic Energy Facility at Ezeiza,” WSRC-TR-200000001 (January 2000).

2 Vinson, D. W., Blanton, P. S., Sindelar, R. L., and Iyer, N. C., "Preliminary Report: Bases for Containment Analysis of Transportation of Aluminum-Based Spent Nuclear Fuel," WSRC-TR98-00317 (October 1998).

3 Hermann, O. W. and Parks, C. V., "SAS2H: A Coupled One-Dimensional Depletion and Shielding Analysis Module,” Oak Ridge National Laboratory, NUREG/DR-0200, Revision 6, Volume 1, Section S2, ORNL/NUREG/CSD-2/V2/R6 (September 1998).

4 Hermann, O. W. and Westfall, R. M., “ORIGEN-S: SCALE System Module to Calculate Fuel Depletion, Actinide Transmutation, Fission Product Buildup and Decay, and Associated Radiation Source Terms," Oak Ridge National Laboratory, NUREG/DR-0200, Revision 6, Volume 2, Section F7, ORNL/NUREG/CSD-2/V2/R6 (September 1998).

5 Draft Appendix A's for assemblies from RA-3 at Comision Nacional De Energiea Atomica, Ezeiza, Prov. De Buenos Aires, Argentina, Draft, DOESRAAF-2000-xxxx No's 1-4, specifically assemblies of No 3 are considered bounding (March 2000).

6 NAC-LWT Cask Safety Analysis Report for Packaging, Volume 2, G0SAR-G000028, Rev 22 (May 1998).

7 Sindelar, R. L. and Howell, J. P., “Radioactivity Release from Aluminum-Based Spent Nuclear Fuel in Basin Storage (U),” WSRC-TR-97-0153 (May 1997).

8 Burke, S. D. “Proposed New Criteria for Acceptance of Al-SNF for SRS Basin Storage (U),” SFSRSE-970167 (February 11, 1998).

9 Vinson, D. W., “Estimate of the Release of Cesium from HMI MTR Assemblies (U),” SRT-MTS98-2012 (March 23, 1998).

10 Vinson, D. W., “Analysis of Debris Found in the GNS-16 Transportation Cask," SRT-MTS-200020008 (April 21, 2000).

11 Haddad, R. E. and Loberse, A. N., “Progress Report for the IAEA CRP on Corrosion of Research Reactor Aluminum-clad Spent Fuel in Water” (February 25, 1999).

12 Chandler, G. T., Sindelar, R. L., and Lam, P-S, “Evaluation of Water Chemistry on the Pitting Susceptibility of Aluminum, " National Association of Corrosion Engineers International, Houston, TX, NACE '97, Paper 104 (March 1997).

13 Louthan, M. R., Jr., et. al, “Corrosion of Aluminum Clad Fuel and Target Elements: The History,” American Nuclear Society Proceedings of the Embedded Topical Meeting on DOE SNF and Fissile Material Management, Reno, NV, pp. 57-66 (June 1996).

14 Gibbs, “SRS Reactor Corrosion Handbook (U),” WSRC-TR-93-42-022, Rev. 0, p.141-142 (March 1993).

15 Sindelar, R. L., Burke, S. D., and Howell, J. P., “Evaluation of Radionuclide Release from Aluminum-Based SNF in Basin Storage," Proceedings of the Third Topical Meeting on DOE Spent Nuclear Fuel and Fissile Materials Management, Charleston, SC, p. 259-264 (September 1998). 


\section{THIS PAGE INTENTIONALLY LEFT BLANK}




\section{A.0 CONTAINMENT CALCULATIONS FOR RA-3 FUEL SHIPMENT}

There are four sources of radioactive material that may become airborne during transportation of breached Al-SNF. These sources are gases, volatiles, fines, and crud. The contributions to the total activity density in the shipping cask free volume from the four sources are treated separately. Therefore, the $A_{2}$ values of the four sources are calculated separately. The following sections provide the details of containment calculations performed for Al-SNF from the RA-3 reactor in Argentina. The calculations follow the prescribed methodology for performing containment analysis as developed at $\mathrm{WSRC}^{1}$ and is consistent with NUREG/CR $6487^{2}, 10 \mathrm{CFR} 71^{3}$, and ANSI N14.5 ${ }^{4}$. For the purpose of this analysis it is assumed that the NAC-LWT shipping cask would be used for transporting the fuel to SRS for the purpose of this analysis. This analysis includes unqualified data and conservative assumptions that have not been subjected to the rigors required for licensing documentation and should not be used as such.

This analysis considers three general cases with different assumptions concerning the degree to which the cladding of the RA-3 spent fuel is breached. In the first or "Best-estimate" case it is assumed that the surface area of exposed fuel meat of the assemblies is derived from records of the visual inspection of the fuel. Consistent with the methodology described in Reference 2, it is assumed that the through clad pitting is limited to the outer fuel plates. The amount of exposed fuel meat per assembly is conservatively assumed equal to $3 \mathrm{~cm}^{3}$, based upon records from the visual inspection of the fuel (see Table 1).

For the second or "Conservative" case, it is conservatively assumed that the corrosion degradation observed on the outer fuel plates represents the maximally degraded fuel plate in the assembly, i.e., the extent of corrosion of the outer plates bounds that of the inner fuel plates. Based upon the records from the visual inspection of the fuel, a conservative value of $3 \mathrm{~cm}^{2}$ is assumed for the amount of exposed fuel meat in a single plate (see Table 1).

In the third or "Bounding" case, extremely conservative values for exposed fuel meat under normal and accident conditions are used. The values assumed in this case are 38 times higher under normal conditions of transport and 120 times higher under accident conditions than the respective values used in the "Best estimate" case. These values are used to demonstrate the extent of breached cladding that can be safely contained in the LWT for normal and accident transport conditions. WSRC Assumes no responsibility in the application of this report to the licensing of the LWT cask for shipment of RA-3 fuel.

\section{A.1 Determination of $A_{2}$ Values for Source Group Mixtures}

Determination of $\mathrm{A}_{2}$ values for individual mixtures of activity sources (i.e., gases, volatiles, fines, and crud) is dependent only on material composition of the fuel meat region. Therefore, the $\mathrm{A}_{2}$ values for the mixtures of gas, volatile, fine, and crud sources for all cases are provided below.

$\mathrm{A}_{2}$ values for the mixtures of sources are derived from the values provided in Appendix A, Table A-1 of 10CFR71. The $A_{2}$ values for those isotopes for which no specific $A_{2}$ value is specified are determined using the guidance provided in the appendix of the referenced regulation. The $\mathrm{A}_{2}$ value for mixtures of isotopes is calculated from:

$$
\mathrm{A}_{2}=\left(\sum\left(\mathrm{R}_{\mathrm{i}} / \mathrm{A}_{2 \mathrm{i}}\right)\right)^{-1}
$$

where:

$\mathrm{R}_{\mathrm{i}} \quad$ is the fraction activity of nuclide $i$ in the mixture and

$\mathrm{A}_{2 \mathrm{i}}$ is the appropriate $\mathrm{A}_{2}$ value for nuclide $i$. 
A mixture $A_{2}$ is determined by the previous equation for each individual activity source. The mixture $A_{2}$ values are calculated in the following tables.

Table A.1 Mixture $A_{2}$ Determination for Gases (per assembly)

\begin{tabular}{|c|c|c|c|c|}
\hline Isotope & $\begin{array}{c}\mathbf{A}_{2}-\text { Value } \\
{[C i]} \\
A_{2 i}\end{array}$ & $\begin{array}{c}\text { Activity } \\
\text { [Ci] } \\
A_{i}\end{array}$ & $\begin{array}{c}\text { Fraction } \\
{[\mathbf{F r}]} \\
\mathbf{R}_{\mathbf{i}}=\mathbf{A}_{\mathrm{i}} / \Sigma \mathbf{A}_{\mathrm{I}}\end{array}$ & $\begin{array}{l}\mathbf{F r} / \mathbf{A}_{2} \\
{[1 / \mathrm{Ci}]} \\
\mathrm{R}_{\mathrm{i}} / \mathrm{A}_{2 \mathrm{i}}\end{array}$ \\
\hline H3 & $1.0800 \mathrm{E}+03$ & $3.7800 \mathrm{E}-04$ & $3.1612 \mathrm{E}-05$ & $2.9271 \mathrm{E}-08$ \\
\hline $\mathrm{H} 3$ & $1.0800 \mathrm{E}+03$ & $4.5700 \mathrm{E}-01$ & $3.8219 \mathrm{E}-02$ & $3.5388 \mathrm{E}-05$ \\
\hline Kr81 & $1.0800 \mathrm{E}+03$ & $3.6800 \mathrm{E}-11$ & $3.0776 \mathrm{E}-12$ & $2.8496 \mathrm{E}-15$ \\
\hline Kr85 & $2.7000 \mathrm{E}+02$ & $1.1500 \mathrm{E}+01$ & $9.6175 \mathrm{E}-01$ & $3.5620 \mathrm{E}-03$ \\
\hline I129 & $1.0000 \mathrm{E}+05$ & $4.7500 \mathrm{E}-05$ & $3.9724 \mathrm{E}-06$ & $3.9724 \mathrm{E}-11$ \\
\hline \multicolumn{2}{|c|}{ Sum Totals: } & $1.1957 \mathrm{E}+01$ & \multicolumn{2}{|c|}{$\sum\left(\mathbf{R}_{\mathbf{i}} / \mathbf{A}_{2 \dot{i}}\right)$} \\
\hline
\end{tabular}

Table A.2 Mixture $A_{2}$ Determination for Volatiles (per assembly)

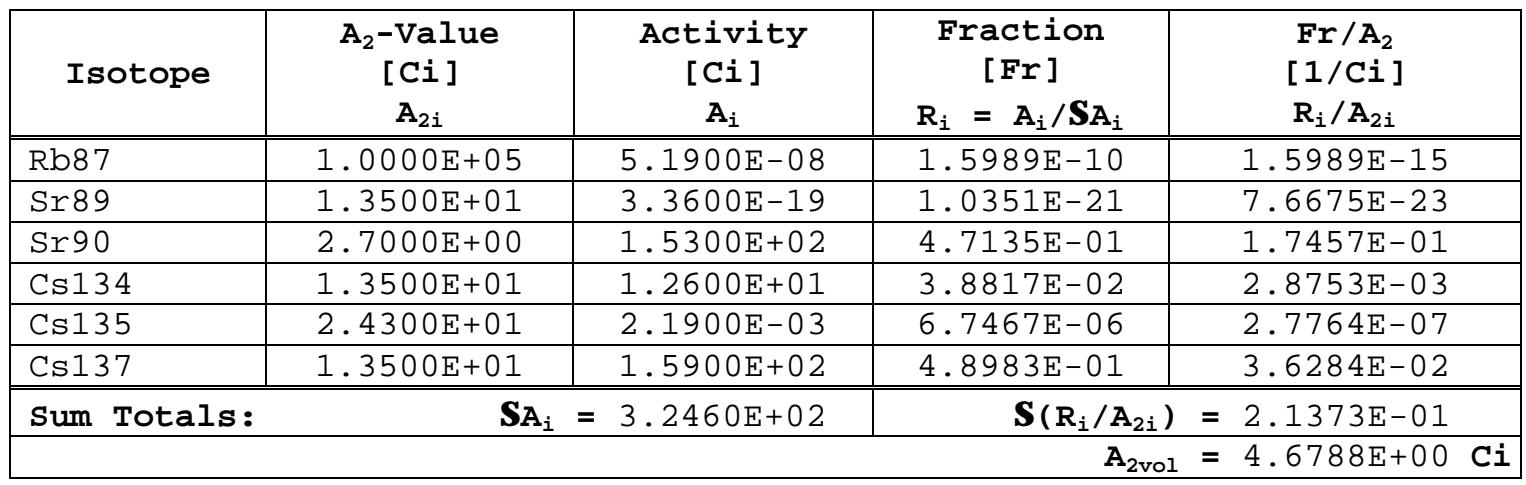

Table A.3 Mixture $A_{2}$ Determination for Fines (per assembly)

\begin{tabular}{|c|c|c|c|c|}
\hline Isotope & $\begin{array}{c}\mathrm{A}_{2}-\mathrm{Value} \\
{[\mathrm{Ci}]} \\
\mathrm{A}_{2 i}\end{array}$ & $\begin{array}{c}\text { Activity } \\
{[\mathrm{Ci}]} \\
\mathrm{A}_{i} \\
\end{array}$ & $\begin{array}{c}\text { Fraction } \\
\text { [Fr] } \\
\mathbf{R}_{\mathbf{i}}=\mathbf{A}_{\mathbf{i}} / \sum \mathbf{A}_{\mathbf{i}}\end{array}$ & $\begin{array}{c}\mathrm{Fr} / \mathrm{A}_{2} \\
{[1 / \mathrm{Ci}]} \\
\mathrm{R}_{\mathrm{i}} / \mathrm{A}_{2 i}\end{array}$ \\
\hline $\mathrm{Na} 22$ & $1.3500 \mathrm{E}+01$ & $2.1000 E-19$ & $2.9816 E-22$ & $2.2086 \mathrm{E}-23$ \\
\hline $\mathrm{Si32}$ & $5.4100 \mathrm{E}+00$ & $3.4800 \mathrm{E}-18$ & $4.9410 \mathrm{E}-21$ & $9.1330 \mathrm{E}-22$ \\
\hline P32 & $8.1100 \mathrm{E}+00$ & $3.4900 E-18$ & $4.9552 \mathrm{E}-21$ & $6.1100 \mathrm{E}-22$ \\
\hline Mn54 & $2.7000 \mathrm{E}+01$ & $2.2700 \mathrm{E}-06$ & $3.2230 E-09$ & $1.1937 \mathrm{E}-10$ \\
\hline Fe59 & $2.1600 \mathrm{E}+01$ & $5.3500 \mathrm{E}-30$ & $7.5960 \mathrm{E}-33$ & $3.5167 \mathrm{E}-34$ \\
\hline Co58 & $2.7000 \mathrm{E}+01$ & $6.8400 E-28$ & $9.7116 \mathrm{E}-31$ & $3.5969 \mathrm{E}-32$ \\
\hline Co60 & $1.0800 \mathrm{E}+01$ & $1.1200 \mathrm{E}-08$ & $1.5902 \mathrm{E}-11$ & $1.4724 \mathrm{E}-12$ \\
\hline $\mathrm{Ni} 63$ & $8.1100 \mathrm{E}+02$ & $7.8800 \mathrm{E}-19$ & 1.1188E-21 & $1.3796 \mathrm{E}-24$ \\
\hline T1206 & $5.0000 \mathrm{E}-01$ & $3.7400 \mathrm{E}-18$ & $5.3101 \mathrm{E}-21$ & $1.0620 \mathrm{E}-20$ \\
\hline T1207 & $5.0000 \mathrm{E}-01$ & $1.1800 \mathrm{E}-08$ & $1.6754 \mathrm{E}-11$ & $3.3508 \mathrm{E}-11$ \\
\hline T1208 & $5.0000 \mathrm{E}-01$ & $1.0600 \mathrm{E}-05$ & $1.5050 \mathrm{E}-08$ & $3.0100 \mathrm{E}-08$ \\
\hline T1209 & $5.0000 \mathrm{E}-01$ & $1.4800 \mathrm{E}-12$ & $2.1013 \mathrm{E}-15$ & $4.2027 \mathrm{E}-15$ \\
\hline $\mathrm{Pb} 209$ & $9.0000 \mathrm{E}-03$ & $7.0600 \mathrm{E}-11$ & $1.0024 \mathrm{E}-13$ & $1.1138 \mathrm{E}-11$ \\
\hline $\mathrm{Pb} 210$ & $2.4300 \mathrm{E}-01$ & $2.8300 \mathrm{E}-12$ & $4.0181 \mathrm{E}-15$ & $1.6535 \mathrm{E}-14$ \\
\hline $\mathrm{Pb} 211$ & $9.0000 \mathrm{E}-03$ & $1.1800 \mathrm{E}-08$ & $1.6754 \mathrm{E}-11$ & $1.8615 \mathrm{E}-09$ \\
\hline $\mathrm{Pb} 212$ & $8.1100 \mathrm{E}+00$ & $2.9600 \mathrm{E}-05$ & $4.2027 \mathrm{E}-08$ & $5.1821 \mathrm{E}-09$ \\
\hline $\mathrm{Pb} 214$ & $2.4300 \mathrm{E}-01$ & $3.2500 E-11$ & $4.6144 E-14$ & $1.8989 \mathrm{E}-13$ \\
\hline
\end{tabular}




\begin{tabular}{|c|c|c|c|c|}
\hline Isotope & $\begin{array}{c}\mathrm{A}_{2}-\mathrm{Value} \\
{[\mathrm{Ci}]} \\
\mathrm{A}_{2 i}\end{array}$ & $\begin{array}{c}\text { Activity } \\
{[C i]} \\
A_{i}\end{array}$ & $\begin{array}{c}\text { Fraction } \\
\text { [Fr] } \\
\mathbf{R}_{\mathbf{i}}=\mathbf{A}_{\mathbf{i}} / \sum \mathbf{A}_{\mathbf{i}}\end{array}$ & $\begin{array}{l}F r / A_{2} \\
{[1 / C i]} \\
R_{i} / A_{2 i}\end{array}$ \\
\hline Bi210 & $1.3500 \mathrm{E}+01$ & $2.8300 \mathrm{E}-12$ & $4.0181 \mathrm{E}-15$ & $2.9764 \mathrm{E}-16$ \\
\hline Bi211 & $5.4100 E-03$ & $1.1800 \mathrm{E}-08$ & $1.6754 \mathrm{E}-11$ & $3.0968 E-09$ \\
\hline Bi212 & $8.1100 \mathrm{E}+00$ & $2.9600 \mathrm{E}-05$ & $4.2027 \mathrm{E}-08$ & $5.1821 E-09$ \\
\hline $\mathrm{Bi} 213$ & $5.0000 E-01$ & $7.0600 \mathrm{E}-11$ & $1.0024 \mathrm{E}-13$ & $2.0048 E-13$ \\
\hline Bi214 & $5.0000 E-01$ & $3.2500 \mathrm{E}-11$ & $4.6144 \mathrm{E}-14$ & $9.2288 E-14$ \\
\hline Po210 & $5.4100 E-01$ & $2.3800 \mathrm{E}-12$ & $3.3792 \mathrm{E}-15$ & $6.2462 E-15$ \\
\hline Po211 & $5.4100 \mathrm{E}-03$ & $3.2600 \mathrm{E}-11$ & $4.6286 \mathrm{E}-14$ & $8.5557 \mathrm{E}-12$ \\
\hline $\mathrm{P} \circ 212$ & $5.4100 \mathrm{E}-01$ & $1.9000 \mathrm{E}-05$ & $2.6977 \mathrm{E}-08$ & $4.9864 \mathrm{E}-08$ \\
\hline Po213 & $5.4100 \mathrm{E}-03$ & $6.9100 \mathrm{E}-11$ & $9.8110 \mathrm{E}-14$ & $1.8135 \mathrm{E}-11$ \\
\hline Po214 & $5.0000 E-01$ & $3.2500 \mathrm{E}-11$ & $4.6144 \mathrm{E}-14$ & $9.2288 E-14$ \\
\hline Po215 & $5.4100 \mathrm{E}-03$ & $1.1800 \mathrm{E}-08$ & $1.6754 \mathrm{E}-11$ & $3.0968 \mathrm{E}-09$ \\
\hline Po216 & $5.4100 E-01$ & $2.9600 E-05$ & $4.2027 \mathrm{E}-08$ & $7.7683 E-08$ \\
\hline Po218 & $5.4100 \mathrm{E}-03$ & $3.2500 \mathrm{E}-11$ & $4.6144 \mathrm{E}-14$ & $8.5294 \mathrm{E}-12$ \\
\hline At 217 & $5.4100 \mathrm{E}-03$ & $7.0600 \mathrm{E}-11$ & $1.0024 \mathrm{E}-13$ & $1.8529 \mathrm{E}-11$ \\
\hline Rn219 & $5.4100 E-03$ & $1.1800 \mathrm{E}-08$ & $1.6754 \mathrm{E}-11$ & $3.0968 E-09$ \\
\hline Rn220 & $5.4100 \mathrm{E}-03$ & $2.9600 \mathrm{E}-05$ & $4.2027 \mathrm{E}-08$ & $7.7683 E-06$ \\
\hline Rn222 & $1.0800 \mathrm{E}-01$ & $3.2500 \mathrm{E}-11$ & $4.6144 \mathrm{E}-14$ & $4.2726 \mathrm{E}-13$ \\
\hline Fr221 & $5.4100 \mathrm{E}-03$ & $7.0600 \mathrm{E}-11$ & $1.0024 \mathrm{E}-13$ & $1.8529 \mathrm{E}-11$ \\
\hline $\operatorname{Fr223}$ & $5.0000 \mathrm{E}-01$ & $1.6300 \mathrm{E}-10$ & $2.3143 E-13$ & $4.6286 \mathrm{E}-13$ \\
\hline Ra223 & $8.1100 \mathrm{E}-01$ & $1.1800 \mathrm{E}-08$ & $1.6754 \mathrm{E}-11$ & $2.0658 \mathrm{E}-11$ \\
\hline Ra224 & $1.6200 \mathrm{E}+00$ & $2.9600 \mathrm{E}-05$ & $4.2027 \mathrm{E}-08$ & $2.5942 E-08$ \\
\hline Ra225 & $5.4100 E-01$ & $7.0600 \mathrm{E}-11$ & $1.0024 \mathrm{E}-13$ & $1.8529 \mathrm{E}-13$ \\
\hline Ra226 & $5.4100 \mathrm{E}-01$ & $3.2500 \mathrm{E}-11$ & $4.6144 \mathrm{E}-14$ & $8.5294 \mathrm{E}-14$ \\
\hline Ra228 & $1.0800 \mathrm{E}+00$ & $3.7700 \mathrm{E}-13$ & $5.3527 \mathrm{E}-16$ & $4.9562 E-16$ \\
\hline Ac225 & $2.7000 E-01$ & $7.0600 \mathrm{E}-11$ & $1.0024 \mathrm{E}-13$ & $3.7126 \mathrm{E}-13$ \\
\hline Ac227 & $5.4100 \mathrm{E}-04$ & $1.1800 \mathrm{E}-08$ & $1.6754 \mathrm{E}-11$ & $3.0968 E-08$ \\
\hline Ac228 & $1.0800 \mathrm{E}+01$ & $3.7700 \mathrm{E}-13$ & $5.3527 E-16$ & $4.9562 \mathrm{E}-17$ \\
\hline Th227 & $2.7000 \mathrm{E}-01$ & $1.1700 \mathrm{E}-08$ & $1.6612 \mathrm{E}-11$ & $6.1526 \mathrm{E}-11$ \\
\hline Th228 & $1.0800 \mathrm{E}-02$ & $2.9600 \mathrm{E}-05$ & $4.2027 E-08$ & $3.8914 \mathrm{E}-06$ \\
\hline Th229 & $8.1100 \mathrm{E}-04$ & $7.0600 \mathrm{E}-11$ & $1.0024 \mathrm{E}-13$ & $1.2360 \mathrm{E}-10$ \\
\hline Th230 & $5.4100 \mathrm{E}-03$ & $1.9800 \mathrm{E}-08$ & $2.8112 \mathrm{E}-11$ & $5.1964 \mathrm{E}-09$ \\
\hline Th231 & $2.4300 \mathrm{E}+01$ & $2.4100 \mathrm{E}-04$ & $3.4218 \mathrm{E}-07$ & $1.4081 \mathrm{E}-08$ \\
\hline Th232 & $1.0000 \mathrm{E}+05$ & $8.0800 \mathrm{E}-13$ & $1.1472 \mathrm{E}-15$ & $1.1472 \mathrm{E}-20$ \\
\hline Th234 & $5.4100 \mathrm{E}+00$ & $5.6900 \mathrm{E}-06$ & $8.0788 \mathrm{E}-09$ & 1.4933E-09 \\
\hline Pa231 & $1.6200 \mathrm{E}-03$ & $6.5000 \mathrm{E}-08$ & $9.2288 \mathrm{E}-11$ & $5.6968 \mathrm{E}-08$ \\
\hline Pa233 & $2.4300 \mathrm{E}+01$ & $2.0800 \mathrm{E}-03$ & $2.9532 \mathrm{E}-06$ & $1.2153 \mathrm{E}-07$ \\
\hline $\mathrm{Pa} 234 \mathrm{~m}$ & $5.0000 \mathrm{E}-01$ & $5.6900 \mathrm{E}-06$ & $8.0788 \mathrm{E}-09$ & $1.6158 \mathrm{E}-08$ \\
\hline $\mathrm{Pa} 234$ & $5.0000 \mathrm{E}-01$ & $7.4000 \mathrm{E}-09$ & $1.0507 \mathrm{E}-11$ & $2.1013 \mathrm{E}-11$ \\
\hline U232 & $8.1100 E-03$ & $3.2600 \mathrm{E}-05$ & $4.6286 \mathrm{E}-08$ & $5.7073 E-06$ \\
\hline U233 & $2.7000 E-02$ & $1.1800 \mathrm{E}-07$ & $1.6754 \mathrm{E}-10$ & $6.2051 E-09$ \\
\hline U234 & $2.7000 \mathrm{E}-02$ & $3.7800 \mathrm{E}-04$ & $5.3669 \mathrm{E}-07$ & $1.9877 \mathrm{E}-05$ \\
\hline U235 & $1.0000 \mathrm{E}+05$ & $2.4100 \mathrm{E}-04$ & $3.4218 \mathrm{E}-07$ & $3.4218 E-12$ \\
\hline $\mathrm{U} 236$ & $2.7000 \mathrm{E}-02$ & $1.4000 \mathrm{E}-03$ & $1.9877 \mathrm{E}-06$ & $7.3620 \mathrm{E}-05$ \\
\hline $\mathrm{U} 237$ & $5.0000 \mathrm{E}-01$ & $7.6100 \mathrm{E}-04$ & $1.0805 \mathrm{E}-06$ & $2.1610 \mathrm{E}-06$ \\
\hline U238 & $1.0000 \mathrm{E}+05$ & $5.6900 \mathrm{E}-06$ & $8.0788 \mathrm{E}-09$ & $8.0788 E-14$ \\
\hline U240 & $5.0000 E-01$ & $1.6100 \mathrm{E}-18$ & $2.2859 \mathrm{E}-21$ & $4.5718 E-21$ \\
\hline Np235 & $1.0800 \mathrm{E}+03$ & $5.0300 \mathrm{E}-08$ & $7.1417 \mathrm{E}-11$ & $6.6127 E-14$ \\
\hline Np236 & $2.7000 \mathrm{E}-02$ & $1.5200 \mathrm{E}-08$ & $2.1581 \mathrm{E}-11$ & $7.9931 E-10$ \\
\hline Np237 & $5.4100 E-03$ & $2.0800 \mathrm{E}-03$ & $2.9532 \mathrm{E}-06$ & $5.4588 E-04$ \\
\hline Np238 & $5.4100 \mathrm{E}-03$ & $2.7500 \mathrm{E}-05$ & $3.9045 \mathrm{E}-08$ & $7.2172 \mathrm{E}-06$ \\
\hline Np239 & $1.3500 \mathrm{E}+01$ & $2.2200 \mathrm{E}-03$ & $3.1520 \mathrm{E}-06$ & $2.3348 E-07$ \\
\hline
\end{tabular}




\begin{tabular}{|c|c|c|c|c|}
\hline Isotope & $\begin{array}{c}\mathrm{A}_{2}-\mathrm{Value} \\
{[\mathrm{Ci}]} \\
\mathrm{A}_{2 \mathrm{i}}\end{array}$ & $\begin{array}{c}\text { Activity } \\
{[\mathrm{Ci}]} \\
\mathrm{A}_{\mathbf{i}} \\
\end{array}$ & $\begin{array}{c}\text { Fraction } \\
\text { [Fr] } \\
\mathbf{R}_{\mathbf{i}}=\mathbf{A}_{\mathrm{i}} / \sum \mathbf{A}_{\mathbf{i}}\end{array}$ & $\begin{array}{l}F r / A_{2} \\
{[1 / C i]} \\
R_{i} / A_{2 i}\end{array}$ \\
\hline $\mathrm{Np} 240 \mathrm{~m}$ & $5.0000 \mathrm{E}-01$ & $1.6100 \mathrm{E}-18$ & $2.2859 \mathrm{E}-21$ & $4.5718 \mathrm{E}-21$ \\
\hline Pu236 & $1.8900 \mathrm{E}-02$ & $6.4100 \mathrm{E}-05$ & $9.1011 \mathrm{E}-08$ & $4.8154 \mathrm{E}-06$ \\
\hline Pu237 & $5.4100 \mathrm{E}+02$ & $2.6600 \mathrm{E}-27$ & $3.7767 \mathrm{E}-30$ & $6.9810 E-33$ \\
\hline Pu238 & $5.4100 \mathrm{E}-03$ & $1.1500 \mathrm{E}+01$ & $1.6328 \mathrm{E}-02$ & $3.0181 \mathrm{E}+00$ \\
\hline Pu239 & $5.4100 \mathrm{E}-03$ & $1.5900 \mathrm{E}-01$ & $2.2575 \mathrm{E}-04$ & $4.1729 \mathrm{E}-02$ \\
\hline Pu240 & $5.4100 \mathrm{E}-03$ & $6.6800 \mathrm{E}-02$ & $9.4844 \mathrm{E}-05$ & $1.7531 \mathrm{E}-02$ \\
\hline Pu241 & $2.7000 \mathrm{E}-01$ & $3.1800 \mathrm{E}+01$ & $4.5150 \mathrm{E}-02$ & $1.6722 \mathrm{E}-01$ \\
\hline Pu242 & $5.4100 \mathrm{E}-03$ & $2.2700 \mathrm{E}-04$ & $3.2230 \mathrm{E}-07$ & $5.9575 \mathrm{E}-05$ \\
\hline Pu243 & $5.0000 \mathrm{E}-01$ & $6.6300 \mathrm{E}-12$ & $9.4134 \mathrm{E}-15$ & $1.8827 \mathrm{E}-14$ \\
\hline Pu244 & $5.4100 \mathrm{E}-03$ & $1.6100 \mathrm{E}-18$ & $2.2859 \mathrm{E}-21$ & $4.2253 \mathrm{E}-19$ \\
\hline Pu246 & $5.0000 \mathrm{E}-01$ & $7.8500 \mathrm{E}-20$ & $1.1146 \mathrm{E}-22$ & $2.2291 \mathrm{E}-22$ \\
\hline Am2 41 & $5.4100 \mathrm{E}-03$ & $7.1100 \mathrm{E}-01$ & $1.0095 \mathrm{E}-03$ & $1.8660 \mathrm{E}-01$ \\
\hline Am2 42m & $5.4100 \mathrm{E}-03$ & $6.1100 \mathrm{E}-03$ & $8.6751 \mathrm{E}-06$ & $1.6035 \mathrm{E}-03$ \\
\hline Am2 42 & $5.0000 \mathrm{E}-01$ & $6.0800 \mathrm{E}-03$ & $8.6325 \mathrm{E}-06$ & $1.7265 \mathrm{E}-05$ \\
\hline Am2 43 & $5.4100 \mathrm{E}-03$ & $2.2200 \mathrm{E}-03$ & $3.1520 \mathrm{E}-06$ & $5.8263 E-04$ \\
\hline Am2 45 & $5.0000 \mathrm{E}-01$ & $5.6800 \mathrm{E}-16$ & $8.0646 \mathrm{E}-19$ & $1.6129 \mathrm{E}-18$ \\
\hline Am2 46 & $5.0000 \mathrm{E}-01$ & $7.8500 \mathrm{E}-20$ & $1.1146 \mathrm{E}-22$ & $2.2291 \mathrm{E}-22$ \\
\hline $\mathrm{Cm} 242$ & $2.7000 \mathrm{E}-01$ & $5.0400 \mathrm{E}-03$ & $7.1559 \mathrm{E}-06$ & $2.6503 E-05$ \\
\hline $\mathrm{Cm} 243$ & $8.1100 \mathrm{E}-03$ & $3.1800 \mathrm{E}-03$ & $4.5150 \mathrm{E}-06$ & $5.5672 \mathrm{E}-04$ \\
\hline $\mathrm{Cm} 244$ & $1.0800 \mathrm{E}-02$ & $1.5300 \mathrm{E}-01$ & $2.1723 E-04$ & $2.0114 \mathrm{E}-02$ \\
\hline $\mathrm{Cm} 245$ & $5.4100 \mathrm{E}-03$ & $4.0800 \mathrm{E}-05$ & $5.7929 E-08$ & $1.0708 \mathrm{E}-05$ \\
\hline $\mathrm{Cm} 246$ & $5.4100 \mathrm{E}-03$ & $1.5800 \mathrm{E}-06$ & $2.2433 E-09$ & $4.1466 \mathrm{E}-07$ \\
\hline $\mathrm{Cm} 247$ & $5.4100 \mathrm{E}-03$ & $6.6300 \mathrm{E}-12$ & $9.4134 \mathrm{E}-15$ & $1.7400 \mathrm{E}-12$ \\
\hline $\mathrm{Cm} 248$ & $1.3500 \mathrm{E}-03$ & $1.9700 \mathrm{E}-11$ & $2.7970 \mathrm{E}-14$ & $2.0719 \mathrm{E}-11$ \\
\hline $\mathrm{Cm} 250$ & $5.0000 \mathrm{E}-01$ & $3.1400 \mathrm{E}-19$ & $4.4582 E-22$ & $8.9165 \mathrm{E}-22$ \\
\hline $\mathrm{Bk} 249$ & $2.1600 \mathrm{E}+00$ & $3.9200 \mathrm{E}-11$ & $5.5657 \mathrm{E}-14$ & $2.5767 \mathrm{E}-14$ \\
\hline $\mathrm{Bk} 250$ & $5.0000 \mathrm{E}-01$ & $9.6500 \mathrm{E}-19$ & $1.3701 \mathrm{E}-21$ & $2.7403 E-21$ \\
\hline $\operatorname{Cf249}$ & $5.4100 \mathrm{E}-03$ & $3.0400 \mathrm{E}-10$ & $4.3163 E-13$ & $7.9783 \mathrm{E}-11$ \\
\hline Cf250 & $1.3500 \mathrm{E}-02$ & $3.1300 \mathrm{E}-10$ & $4.4440 \mathrm{E}-13$ & $3.2919 \mathrm{E}-11$ \\
\hline $\operatorname{Cf251}$ & $5.4100 \mathrm{E}-03$ & $5.0700 \mathrm{E}-12$ & $7.1985 \mathrm{E}-15$ & $1.3306 \mathrm{E}-12$ \\
\hline $\operatorname{Cf252}$ & $2.7000 \mathrm{E}-02$ & $2.4400 \mathrm{E}-11$ & $3.4644 \mathrm{E}-14$ & $1.2831 \mathrm{E}-12$ \\
\hline Es254 & $8.1100 \mathrm{E}-02$ & $9.2100 \mathrm{E}-19$ & $1.3077 \mathrm{E}-21$ & $1.6124 \mathrm{E}-20$ \\
\hline $\mathrm{Be} 10$ & $1.3500 \mathrm{E}+01$ & $5.6000 \mathrm{E}-09$ & $7.9510 \mathrm{E}-12$ & $5.8896 \mathrm{E}-13$ \\
\hline $\mathrm{C} 14$ & $5.4100 \mathrm{E}+01$ & $2.2600 \mathrm{E}-07$ & $3.2088 \mathrm{E}-10$ & $5.9312 \mathrm{E}-12$ \\
\hline Se79 & $5.4100 \mathrm{E}+01$ & $1.3400 \mathrm{E}-04$ & $1.9026 \mathrm{E}-07$ & $3.5167 \mathrm{E}-09$ \\
\hline Y89m & $5.4100 \mathrm{E}+01$ & $3.1200 \mathrm{E}-23$ & $4.4298 E-26$ & $8.1882 \mathrm{E}-28$ \\
\hline Y90 & $5.4100 \mathrm{E}+00$ & $1.5400 \mathrm{E}+02$ & $2.1865 \mathrm{E}-01$ & $4.0416 \mathrm{E}-02$ \\
\hline Y91 & $8.1100 \mathrm{E}+00$ & $3.7500 \mathrm{E}-16$ & $5.3243 \mathrm{E}-19$ & $6.5651 \mathrm{E}-20$ \\
\hline $\mathrm{Nb} 91$ & $1.3500 \mathrm{E}+01$ & $4.6100 \mathrm{E}-12$ & $6.5454 \mathrm{E}-15$ & $4.8484 \mathrm{E}-16$ \\
\hline $\mathrm{Nb} 92$ & $1.3500 \mathrm{E}+01$ & $1.1900 \mathrm{E}-14$ & $1.6896 \mathrm{E}-17$ & $1.2515 \mathrm{E}-18$ \\
\hline Zr93 & $5.4100 \mathrm{E}+00$ & $2.6700 \mathrm{E}-03$ & $3.7909 \mathrm{E}-06$ & $7.0072 \mathrm{E}-07$ \\
\hline $\mathrm{Nb} 93 \mathrm{~m}$ & $1.6200 \mathrm{E}+02$ & $1.0500 \mathrm{E}-03$ & $1.4908 \mathrm{E}-06$ & $9.2025 \mathrm{E}-09$ \\
\hline $\mathrm{Nb} 94$ & $1.6200 \mathrm{E}+01$ & $8.5500 \mathrm{E}-08$ & $1.2139 \mathrm{E}-10$ & $7.4935 \mathrm{E}-12$ \\
\hline Zr95 & $2.4300 \mathrm{E}+01$ & $1.7300 \mathrm{E}-14$ & $2.4563 \mathrm{E}-17$ & $1.0108 \mathrm{E}-18$ \\
\hline $\mathrm{Nb} 95$ & $2.7000 \mathrm{E}+01$ & $3.8000 \mathrm{E}-14$ & $5.3953 \mathrm{E}-17$ & $1.9983 \mathrm{E}-18$ \\
\hline $\mathrm{Nb} 95 \mathrm{~m}$ & $2.4300 \mathrm{E}+01$ & $2.0300 \mathrm{E}-16$ & $2.8822 \mathrm{E}-19$ & $1.1861 \mathrm{E}-20$ \\
\hline TC98 & $1.8900 \mathrm{E}+01$ & $3.4300 \mathrm{E}-09$ & $4.8700 \mathrm{E}-12$ & $2.5767 \mathrm{E}-13$ \\
\hline TC99 & $2.4300 \mathrm{E}+01$ & $2.4600 \mathrm{E}-02$ & $3.4928 \mathrm{E}-05$ & $1.4373 \mathrm{E}-06$ \\
\hline Rh102 & $1.3500 \mathrm{E}+01$ & $6.0900 \mathrm{E}-05$ & $8.6467 \mathrm{E}-08$ & $6.4050 \mathrm{E}-09$ \\
\hline Ru103 & $2.4300 \mathrm{E}+01$ & $1.2800 \mathrm{E}-25$ & $1.8174 \mathrm{E}-28$ & $7.4789 \mathrm{E}-30$ \\
\hline Ru106 & $5.4100 \mathrm{E}+00$ & $2.3500 \mathrm{E}-01$ & $3.3366 \mathrm{E}-04$ & $6.1674 \mathrm{E}-05$ \\
\hline
\end{tabular}




\begin{tabular}{|c|c|c|c|c|}
\hline Isotope & $\begin{array}{c}\mathrm{A}_{2}-\mathrm{Value} \\
{[\mathrm{Ci}]} \\
\mathrm{A}_{2 \mathrm{i}}\end{array}$ & $\begin{array}{c}\text { Activity } \\
{[\mathrm{Ci}]} \\
\mathrm{A}_{i}\end{array}$ & $\begin{array}{c}\text { Fraction } \\
\text { [Fr] } \\
\mathbf{R}_{\mathbf{i}}=\mathbf{A}_{\mathrm{i}} / \Sigma \mathbf{A}_{\mathbf{i}}\end{array}$ & $\begin{array}{l}\operatorname{Fr} / \mathrm{A}_{2} \\
{[1 / \mathrm{Ci}]} \\
\mathrm{R}_{\mathrm{i}} / \mathrm{A}_{2 i}\end{array}$ \\
\hline Rh106 & $5.0000 \mathrm{E}-01$ & $2.3500 \mathrm{E}-01$ & $3.3366 \mathrm{E}-04$ & $6.6732 \mathrm{E}-04$ \\
\hline Pd107 & $1.0000 \mathrm{E}+05$ & $3.4900 \mathrm{E}-05$ & $4.9552 E-08$ & $4.9552 E-13$ \\
\hline $\operatorname{Ag} 108$ & $5.0000 \mathrm{E}-01$ & $3.0300 \mathrm{E}-08$ & $4.3021 \mathrm{E}-11$ & $8.6041 E-11$ \\
\hline $\operatorname{Ag} 108 m$ & $1.3500 \mathrm{E}+01$ & $3.4800 \mathrm{E}-07$ & $4.9410 \mathrm{E}-10$ & $3.6600 \mathrm{E}-11$ \\
\hline $\operatorname{Ag} 109 m$ & $5.0000 \mathrm{E}-01$ & $1.9300 \mathrm{E}-10$ & $2.7403 E-13$ & $5.4805 \mathrm{E}-13$ \\
\hline Cd109 & $2.7000 \mathrm{E}+01$ & $1.9300 \mathrm{E}-10$ & $2.7403 E-13$ & $1.0149 \mathrm{E}-14$ \\
\hline $\operatorname{Ag} 110$ & $2.4400 \mathrm{E}+01$ & $5.1700 \mathrm{E}-07$ & $7.3405 \mathrm{E}-10$ & $3.0084 \mathrm{E}-11$ \\
\hline $\operatorname{Ag} 110 \mathrm{~m}$ & $1.0800 \mathrm{E}+01$ & $3.8000 E-05$ & $5.3953 E-08$ & $4.9957 \mathrm{E}-09$ \\
\hline $\operatorname{cd} 113$ & $5.0000 \mathrm{E}-01$ & $1.2400 \mathrm{E}-16$ & $1.7606 \mathrm{E}-19$ & $3.5212 E-19$ \\
\hline $\operatorname{cd} 113 \mathrm{~m}$ & $2.4300 \mathrm{E}+00$ & $1.3500 \mathrm{E}-02$ & $1.9168 \mathrm{E}-05$ & $7.8879 \mathrm{E}-06$ \\
\hline $\operatorname{In} 114 \mathrm{~m}$ & $8.1100 \mathrm{E}+00$ & $7.2800 \mathrm{E}-26$ & $1.0336 \mathrm{E}-28$ & $1.2745 \mathrm{E}-29$ \\
\hline $\mathrm{Cd} 115 \mathrm{~m}$ & $8.1100 \mathrm{E}+00$ & $5.1800 \mathrm{E}-26$ & $7.3547 \mathrm{E}-29$ & $9.0686 \mathrm{E}-30$ \\
\hline $\operatorname{In} 115$ & $5.0000 \mathrm{E}-01$ & $1.0900 \mathrm{E}-14$ & $1.5476 \mathrm{E}-17$ & $3.0952 \mathrm{E}-17$ \\
\hline Sn119m & $1.0800 \mathrm{E}+03$ & $1.0600 \mathrm{E}-05$ & $1.5050 \mathrm{E}-08$ & $1.3935 \mathrm{E}-11$ \\
\hline $\operatorname{Sn} 121$ & $1.3500 \mathrm{E}+01$ & $1.1900 \mathrm{E}-03$ & $1.6896 \mathrm{E}-06$ & $1.2515 \mathrm{E}-07$ \\
\hline $\mathrm{Sn} 121 \mathrm{~m}$ & $2.4300 \mathrm{E}+01$ & $1.5300 \mathrm{E}-03$ & $2.1723 E-06$ & $8.9396 \mathrm{E}-08$ \\
\hline $\operatorname{Sn} 123$ & $1.3500 \mathrm{E}+01$ & $2.2800 \mathrm{E}-09$ & $3.2372 \mathrm{E}-12$ & $2.3979 E-13$ \\
\hline Te123 & $5.4100 \mathrm{E}+00$ & $6.7500 \mathrm{E}-16$ & $9.5838 \mathrm{E}-19$ & $1.7715 \mathrm{E}-19$ \\
\hline Te123m & $1.8900 \mathrm{E}+02$ & $3.5700 \mathrm{E}-12$ & $5.0688 \mathrm{E}-15$ & $2.6819 \mathrm{E}-17$ \\
\hline Sb124 & $1.3500 \mathrm{E}+01$ & $3.5200 \mathrm{E}-19$ & $4.9978 E-22$ & $3.7021 E-23$ \\
\hline Sb125 & $2.4300 \mathrm{E}+01$ & $6.1300 \mathrm{E}-01$ & $8.7035 \mathrm{E}-04$ & $3.5817 \mathrm{E}-05$ \\
\hline Te125m & $2.4300 \mathrm{E}+02$ & $1.5000 \mathrm{E}-01$ & $2.1297 \mathrm{E}-04$ & $8.7643 E-07$ \\
\hline $\operatorname{Sn} 126$ & $8.1100 \mathrm{E}+00$ & $4.8500 E-04$ & $6.8861 \mathrm{E}-07$ & $8.4909 \mathrm{E}-08$ \\
\hline Sb126 & $1.0800 \mathrm{E}+01$ & $6.7900 \mathrm{E}-05$ & $9.6406 \mathrm{E}-08$ & $8.9265 E-09$ \\
\hline $\mathrm{Sb} 126 \mathrm{~m}$ & $5.0000 \mathrm{E}-01$ & $4.8500 E-04$ & $6.8861 \mathrm{E}-07$ & $1.3772 \mathrm{E}-06$ \\
\hline Te127 & $1.3500 \mathrm{E}+01$ & $8.3100 \mathrm{E}-10$ & $1.1799 \mathrm{E}-12$ & $8.7398 E-14$ \\
\hline Te127m & $1.3500 \mathrm{E}+01$ & $8.4800 \mathrm{E}-10$ & $1.2040 \mathrm{E}-12$ & $8.9186 \mathrm{E}-14$ \\
\hline Te129m & $1.3500 \mathrm{E}+01$ & $1.0900 \mathrm{E}-31$ & $1.5476 \mathrm{E}-34$ & $1.1464 \mathrm{E}-35$ \\
\hline Ba133 & $8.1100 \mathrm{E}+01$ & $4.2400 \mathrm{E}-09$ & $6.0200 \mathrm{E}-12$ & $7.4230 \mathrm{E}-14$ \\
\hline $\mathrm{Ba} 137 \mathrm{~m}$ & $5.0000 \mathrm{E}-01$ & $1.5100 \mathrm{E}+02$ & $2.1439 \mathrm{E}-01$ & $4.2879 \mathrm{E}-01$ \\
\hline La138 & $1.0800 \mathrm{E}+01$ & $3.7300 \mathrm{E}-13$ & $5.2959 \mathrm{E}-16$ & $4.9036 \mathrm{E}-17$ \\
\hline Ce139 & $1.6200 \mathrm{E}+02$ & $2.9300 \mathrm{E}-12$ & $4.1601 \mathrm{E}-15$ & $2.5679 \mathrm{E}-17$ \\
\hline Ce141 & $1.3500 \mathrm{E}+01$ & $3.3700 E-31$ & $4.7848 E-34$ & $3.5443 E-35$ \\
\hline $\mathrm{Ce} 142$ & $5.0000 \mathrm{E}-01$ & $5.5600 \mathrm{E}-08$ & $7.8942 \mathrm{E}-11$ & $1.5788 \mathrm{E}-10$ \\
\hline Ce144 & $5.4100 \mathrm{E}+00$ & $3.0000 \mathrm{E}-01$ & $4.2595 \mathrm{E}-04$ & $7.8733 E-05$ \\
\hline $\operatorname{Pr} 144$ & $5.0000 \mathrm{E}-01$ & $3.0000 \mathrm{E}-01$ & $4.2595 \mathrm{E}-04$ & $8.5189 \mathrm{E}-04$ \\
\hline $\operatorname{Pr} 144 \mathrm{~m}$ & $5.0000 \mathrm{E}-01$ & $4.2000 \mathrm{E}-03$ & $5.9632 \mathrm{E}-06$ & $1.1926 \mathrm{E}-05$ \\
\hline $\operatorname{Nd144}$ & $1.3500 \mathrm{E}+01$ & $2.8700 \mathrm{E}-12$ & $4.0749 E-15$ & $3.0184 \mathrm{E}-16$ \\
\hline $\operatorname{Pm} 145$ & $1.8900 \mathrm{E}+02$ & $1.2600 \mathrm{E}-06$ & $1.7890 \mathrm{E}-09$ & $9.4655 E-12$ \\
\hline $\operatorname{Sm} 145$ & $5.4100 \mathrm{E}+02$ & $1.3900 \mathrm{E}-09$ & $1.9736 \mathrm{E}-12$ & $3.6480 E-15$ \\
\hline $\operatorname{Pm} 146$ & $1.3500 \mathrm{E}+01$ & $5.4000 \mathrm{E}-04$ & $7.6670 \mathrm{E}-07$ & $5.6793 \mathrm{E}-08$ \\
\hline $\operatorname{Sm} 146$ & $1.3500 \mathrm{E}+01$ & $1.1300 \mathrm{E}-10$ & $1.6044 \mathrm{E}-13$ & $1.1884 \mathrm{E}-14$ \\
\hline $\operatorname{Pm} 147$ & $2.4300 \mathrm{E}+01$ & $1.8800 \mathrm{E}+01$ & $2.6693 \mathrm{E}-02$ & $1.0985 \mathrm{E}-03$ \\
\hline $\operatorname{Sm} 147$ & $1.0000 \mathrm{E}+05$ & $9.2400 \mathrm{E}-09$ & $1.3119 \mathrm{E}-11$ & $1.3119 \mathrm{E}-16$ \\
\hline $\mathrm{Pm} 148 \mathrm{~m}$ & $1.3500 \mathrm{E}+01$ & $2.0800 E-25$ & $2.9532 E-28$ & $2.1876 \mathrm{E}-29$ \\
\hline $\operatorname{Sm} 148$ & $1.3500 \mathrm{E}+01$ & $9.7100 \mathrm{E}-14$ & $1.3786 \mathrm{E}-16$ & $1.0212 \mathrm{E}-17$ \\
\hline $\operatorname{Sm} 149$ & $1.3500 \mathrm{E}+01$ & $7.1200 \mathrm{E}-15$ & $1.0109 \mathrm{E}-17$ & $7.4882 \mathrm{E}-19$ \\
\hline Eu149 & $5.4100 \mathrm{E}+02$ & $7.4800 \mathrm{E}-22$ & $1.0620 \mathrm{E}-24$ & $1.9631 \mathrm{E}-27$ \\
\hline Eu150 & $1.8900 \mathrm{E}+01$ & $1.8100 \mathrm{E}-08$ & $2.5699 \mathrm{E}-11$ & $1.3597 \mathrm{E}-12$ \\
\hline Sm151 & $1.0800 \mathrm{E}+02$ & $1.7700 \mathrm{E}+00$ & $2.5131 \mathrm{E}-03$ & $2.3269 \mathrm{E}-05$ \\
\hline Eu152 & $2.4300 \mathrm{E}+01$ & $2.9000 \mathrm{E}-02$ & $4.1175 \mathrm{E}-05$ & $1.6944 \mathrm{E}-06$ \\
\hline
\end{tabular}




\begin{tabular}{|c|c|c|c|c|}
\hline Isotope & $\begin{array}{c}\mathbf{A}_{2}-\text { Value } \\
{[C i]} \\
\mathbf{A}_{2 i}\end{array}$ & $\begin{array}{c}\text { Activity } \\
\text { [Ci] } \\
\mathbf{A}_{i}\end{array}$ & $\begin{array}{c}\text { Fraction } \\
{[\mathbf{F r}]} \\
\mathbf{R}_{\mathbf{i}}=\mathbf{A}_{\mathbf{i}} / \Sigma \mathbf{A}_{\mathbf{i}}\end{array}$ & $\begin{array}{c}F r / A_{2} \\
{[1 / C i]} \\
R_{i} / A_{2 i}\end{array}$ \\
\hline Gd152 & $5.4100 \mathrm{E}-03$ & $5.6600 \mathrm{E}-15$ & $8.0362 \mathrm{E}-18$ & $1.4854 \mathrm{E}-15$ \\
\hline Gd153 & $1.3500 \mathrm{E}+02$ & $1.2700 \mathrm{E}-06$ & $1.8032 \mathrm{E}-09$ & $1.3357 \mathrm{E}-11$ \\
\hline Eu154 & $1.3500 \mathrm{E}+01$ & $6.9600 \mathrm{E}+00$ & $9.8820 \mathrm{E}-03$ & $7.3200 \mathrm{E}-04$ \\
\hline Eu155 & $5.4100 \mathrm{E}+01$ & $8.4700 \mathrm{E}-01$ & $1.2026 \mathrm{E}-03$ & $2.2229 \mathrm{E}-05$ \\
\hline Tb160 & $1.3500 \mathrm{E}+01$ & $1.4800 \mathrm{E}-16$ & $2.1013 E-19$ & $1.5565 \mathrm{E}-20$ \\
\hline Ho1 $66 \mathrm{~m}$ & $8.1100 \mathrm{E}+00$ & $3.0900 \mathrm{E}-08$ & $4.3872 \mathrm{E}-11$ & $5.4097 \mathrm{E}-12$ \\
\hline $\operatorname{Tm} 170$ & $1.3500 \mathrm{E}+01$ & $1.2800 \mathrm{E}-17$ & $1.8174 \mathrm{E}-20$ & $1.3462 \mathrm{E}-21$ \\
\hline $\operatorname{Tm} 171$ & $2.7000 \mathrm{E}+02$ & $1.7000 \mathrm{E}-08$ & $2.4137 \mathrm{E}-11$ & $8.9396 \mathrm{E}-14$ \\
\hline $\mathrm{Rb} 87$ & $1.0000 \mathrm{E}+05$ & $5.1900 \mathrm{E}-08$ & $7.3689 \mathrm{E}-11$ & $7.3689 \mathrm{E}-16$ \\
\hline Sr89 & $1.3500 \mathrm{E}+01$ & $3.3600 \mathrm{E}-19$ & $4.7706 \mathrm{E}-22$ & $3.5338 E-23$ \\
\hline Sr90 & $2.7000 \mathrm{E}+00$ & $1.5300 \mathrm{E}+02$ & $2.1723 E-01$ & $8.0457 \mathrm{E}-02$ \\
\hline Cs134 & $1.3500 \mathrm{E}+01$ & $1.2600 \mathrm{E}+01$ & $1.7890 \mathrm{E}-02$ & $1.3252 \mathrm{E}-03$ \\
\hline Cs135 & $2.4300 \mathrm{E}+01$ & $2.1900 \mathrm{E}-03$ & $3.1094 \mathrm{E}-06$ & $1.2796 \mathrm{E}-07$ \\
\hline $\mathrm{Cs} 137$ & $1.3500 \mathrm{E}+01$ & $1.5900 \mathrm{E}+02$ & $2.2575 \mathrm{E}-01$ & $1.6722 \mathrm{E}-02$ \\
\hline \multicolumn{3}{|l|}{ Sum Totals: } & \multicolumn{2}{|c|}{$\Sigma\left(\mathbf{R}_{\mathbf{i}} / \mathbf{A}_{\mathbf{2 i}}\right)=4.0261 \mathrm{E}+00$} \\
\hline & & & & $=2.4838 \mathrm{E}-01 \mathrm{Ci}$ \\
\hline
\end{tabular}

The $A_{2}$ value for the crud associated with this fuel is provided by Reference 1 as 0.270 curies.

\section{A.2 Determination of Activity Density within the Cask Free Volume}

The activity density of releasable activity present the free volume of the cask is dependent on assembly geometry, source release fraction, number of assemblies exhibiting through-clad pitting penetrations, and cask free volume. Additionally, calculation for the releasable fines activity is dependent on degradation behavior of the exposed fuel meat region and on the extent to which the fuel meat is exposed due to through-clad pitting. Excepting the amount of exposed fuel meat, all parameters for determination of activity density within the cask free volume would be identical for the best estimate, conservative, and the bounding cases. Therefore, only the activity density within the cask free volume due to the release of fines is treated separately for the three cases.

\section{A.2.1 Activity Density of Gases}

The releasable activity density inside the containment vessel due to the release of gas is described by:

$$
\mathrm{C}_{\mathrm{gas}}=\left(\mathrm{A}_{\mathrm{G}} \bullet \mathrm{f}_{\mathrm{b}} \bullet \mathrm{f}_{\mathrm{G}}\right) / \mathrm{V}_{\mathrm{C}}
$$

where:

$\mathrm{A}_{\mathrm{G}}$ is the total number of curies of all gaseous radionuclides in all assemblies (42) in the cask. It is the product of the number of assemblies and the number of curies of all gaseous isotopes per assembly (i.e., as output by ORIGEN-S) [5.02E+2-Ci],

$\mathrm{f}_{\mathrm{b}} \quad$ is the fraction of fuel assemblies in a cask that are breached $\left[\mathrm{f}_{\mathrm{b}, \mathrm{N}}=1.0, \mathrm{f}_{\mathrm{b}, \mathrm{A}}=1.0\right]$,

$\mathrm{f}_{\mathrm{G}}$ is the fraction of gas that escapes the breached fuel assembly $\left[\mathrm{f}_{\mathrm{G}, \mathrm{N}}=0.3, \mathrm{f}_{\mathrm{G}, \mathrm{A}}=1.0\right]$,

$\mathrm{V}_{\mathrm{C}}$ is the free volume of the cask $\left[2.293 \mathrm{E}+5-\mathrm{cm}^{3}\right]$,

The releasable activity density inside the containment vessel due to the release of gas is thus: 


$$
\begin{aligned}
\mathrm{C}_{\text {gas }, \mathrm{N}} & =(5.02 \mathrm{E}+2 \cdot 1.0 \bullet 0.3) / 2.293 \mathrm{E}+5=6.57 \mathrm{E}-4 \mathrm{Ci} / \mathrm{cm}^{3} \\
\mathrm{C}_{\text {gas }, \mathrm{A}} & =(5.02 \mathrm{E}+2 \cdot 1.0 \bullet 1.0) / 2.293 \mathrm{E}+5=2.19 \mathrm{E}-3 \mathrm{Ci} / \mathrm{cm}^{3}
\end{aligned}
$$

\section{A.2.2 Activity Density of Volatiles}

The releasable activity density inside the containment vessel due to the release of volatiles is described by:

$$
\mathrm{C}_{\mathrm{vol}}=\left(\mathrm{A}_{\mathrm{V}} \bullet \mathrm{f}_{\mathrm{b}} \bullet \mathrm{f}_{\mathrm{V}}\right) / \mathrm{V}_{\mathrm{C}}
$$

where:

$\mathrm{A}_{\mathrm{V}}$ is the total number of curies of all volatile radionuclides in an assembly. It is the product of the number of assemblies and the number of curies of all volatile isotopes per assembly (i.e., as output by ORIGEN-S) [1.36E+4-Ci],

$\mathrm{f}_{\mathrm{b}} \quad$ is the fraction of fuel assemblies that are breached in a cask $\left[\mathrm{f}_{\mathrm{b}, \mathrm{N}}=1.0, \mathrm{f}_{\mathrm{b}, \mathrm{A}}=1.0\right]$,

$f_{V}$ is the fraction of volatiles that escape the breached fuel assembly $\left[f_{V, N}=f_{V, A}=1 E-6\right]$,

$\mathrm{V}_{\mathrm{C}}$ is the free volume of the cask $\left[2.293 \mathrm{E}+5-\mathrm{cm}^{3}\right]$,

The releasable activity density inside the containment vessel due to the release of volatiles is thus:

$$
\begin{aligned}
& \mathrm{C}_{\mathrm{vol}, \mathrm{N}}=(1.36 \mathrm{E}+4 \cdot 1.0 \cdot 1 \mathrm{E}-6) / 2.293 \mathrm{E}+5=5.95 \mathrm{E}-8 \mathrm{Ci} / \mathrm{cm}^{3} \\
& \mathrm{C}_{\mathrm{vol}, \mathrm{A}}=(1.36 \mathrm{E}+4 \cdot 1.0 \cdot 1 \mathrm{E}-6) / 2.293 \mathrm{E}+5=5.95 \mathrm{E}-8 \mathrm{Ci} / \mathrm{cm}^{3}
\end{aligned}
$$

\section{A.2.3 Activity Density of Fines}

Because the assumed surface area of exposed meat is different for the bounding case from the best estimate case, the activity density calculations are treated separately in the following sections.

\section{A.2.3.1 Activity Density Calculation for Fines in the Best Estimate Case}

The releasable activity density inside the containment vessel due to the release of fines is described by:

$$
\mathrm{C}_{\text {fines }}=\left(\mathrm{A}_{\mathrm{F}} \cdot \mathrm{ESA} \cdot \mathrm{P} \cdot \mathrm{T}_{\mathrm{F}} / \mathrm{V}_{\mathrm{M}}\right) \cdot\left(1 / \mathrm{V}_{\mathrm{C}}\right) \text {, }
$$

where:

$\mathrm{A}_{\mathrm{F}} \quad$ is the total number of curies of all radionuclides in all assemblies in the cask (excluding gases). It is the product of the number of assemblies and the number of curies of the all isotopes (excluding gases) per assembly (i.e., as output by ORIGEN-S) [2.96E+4-Ci],

ESA is the amount of exposed meat surface area per cask $\left[\mathrm{ESA}_{\mathrm{N}}=1.26 \mathrm{E}+2-\mathrm{cm}^{2} / \mathrm{cask}\right.$, $\left.\mathrm{ESA}_{\mathrm{A}}=2.52 \mathrm{E}+2-\mathrm{cm}^{2} / \mathrm{cask}\right]$,

$\mathrm{P} \quad$ is the depth of corrosion attack [5.E-04-cm],

$\mathrm{T}_{\mathrm{F}} \quad$ is the oxide spallation fraction $\left[\mathrm{T}_{\mathrm{F}, \mathrm{N}}=0.15, \mathrm{~T}_{\mathrm{F}, \mathrm{A}}=1.0\right]$

$\mathrm{V}_{\mathrm{M}}$ is the volume of the meat region of the fuel per cask [1.62E $+4-\mathrm{cm}^{3} / \mathrm{cask}$ ], and

$\mathrm{V}_{\mathrm{C}}$ is the free volume of the cask $\left[2.293 \mathrm{E}+5-\mathrm{cm}^{3}\right]$.

The releasable activity density inside the containment vessel due to the release of fines is thus: 


$$
\begin{aligned}
& \mathrm{C}_{\text {fines, } \mathrm{N}}=(2.96 \mathrm{E}+4 \cdot 1.26 \mathrm{E}+2 \cdot 5 \mathrm{E}-4 \cdot 0.15 / 1.62 \mathrm{E}+4) \cdot(1 / 2.293 \mathrm{E}+5)=7.52 \mathrm{E}-8 \mathrm{Ci} / \mathrm{cm}^{3} \\
& \mathrm{C}_{\text {fines }, \mathrm{A}}=(2.96 \mathrm{E}+4 \cdot 2.52 \mathrm{E}+2 \cdot 5 \mathrm{E}-4 \cdot 1.0 / 1.62 \mathrm{E}+4) \cdot(1 / 2.293 \mathrm{E}+5)=1.00 \mathrm{E}-6 \mathrm{Ci} / \mathrm{cm}^{3}
\end{aligned}
$$

\section{A.2.3.2 Activity Density Calculation for Fines in the Conservative Estimate Case}

The releasable activity density inside the containment vessel due to the release of fines is described by:

$$
\mathrm{C}_{\text {fines }}=\left(\mathrm{A}_{\mathrm{F}} \cdot \mathrm{ESA} \cdot \mathrm{P} \cdot \mathrm{T}_{\mathrm{F}} / \mathrm{V}_{\mathrm{M}}\right) \cdot\left(1 / \mathrm{V}_{\mathrm{C}}\right),
$$

where:

$\mathrm{A}_{\mathrm{F}} \quad$ is the total number of curies of all radionuclides in all assemblies in the cask (excluding gases). It is the product of the number of assemblies and the number of curies of the all isotopes (excluding gases) per assembly (i.e., as output by ORIGEN-S) [2.96E+4-Ci],

ESA is the amount of exposed meat surface area per cask $\left[\mathrm{ESA}_{N}=2.39 \mathrm{E}+3-\mathrm{cm} / \mathrm{cask}\right.$, $\left.\mathrm{ESA}_{\mathrm{A}}=4.79 \mathrm{E}+3-\mathrm{cm}^{2} / \mathrm{cask}\right]$

$\mathrm{P} \quad$ is the depth of corrosion attack [5.E-04-cm],

$\mathrm{T}_{\mathrm{F}}$ is the oxide spallation fraction $\left[\mathrm{T}_{\mathrm{F}, \mathrm{N}}=0.15, \mathrm{~T}_{\mathrm{F}, \mathrm{A}}=1.0\right]$

$\mathrm{V}_{\mathrm{M}}$ is the volume of the meat region of the fuel per cask [1.62E $+4-\mathrm{cm}^{3} / \mathrm{cask}$, and

$\mathrm{V}_{\mathrm{C}}$ is the free volume of the cask $\left[2.293 \mathrm{E}+5-\mathrm{cm}^{3}\right]$.

The releasable activity density inside the containment vessel due to the release of fines is thus:

$$
\begin{aligned}
& \mathrm{C}_{\text {fines }, \mathrm{N}}=(2.96 \mathrm{E}+4 \cdot 2.39 \mathrm{E}+3 \cdot 5 \mathrm{E}-4 \cdot 0.15 / 1.62 \mathrm{E}+4) \cdot(1 / 2.293 \mathrm{E}+5)=1.43 \mathrm{E}-6 \mathrm{Ci} / \mathrm{cm}^{3} \\
& \mathrm{C}_{\text {fines } \mathrm{A}}=(2.96 \mathrm{E}+4 \cdot 4.79 \mathrm{E}+3 \cdot 5 \mathrm{E}-4 \cdot 1.0 / 1.62 \mathrm{E}+4) \cdot(1 / 2.293 \mathrm{E}+5)=1.90 \mathrm{E}-5 \mathrm{Ci} / \mathrm{cm}^{3}
\end{aligned}
$$

\section{A.2.3.3 Activity Density Calculation for Fines in the Bounding Case}

The releasable activity density inside the containment vessel due to the release of fines is described by:

$$
\mathrm{C}_{\text {fines }}=\left(\mathrm{A}_{\mathrm{F}} \cdot \mathrm{ESA} \cdot \mathrm{P} \cdot \mathrm{T}_{\mathrm{F}} / \mathrm{V}_{\mathrm{M}}\right) \cdot\left(1 / \mathrm{V}_{\mathrm{C}}\right) \text {, }
$$

where:

$\mathrm{A}_{\mathrm{F}} \quad$ is the total number of curies of all radionuclides in all assemblies in the cask (excluding gases). It is the product of the number of assemblies and the number of curies of the all isotopes (excluding gases) per assembly (i.e., as output by ORIGEN-S) [2.96E+4-Ci],

ESA is the amount of exposed meat surface area per cask $\left[\mathrm{ESA}_{N}=9.06 \mathrm{E}+4-\mathrm{cm}^{2} / \mathrm{cask}\right.$, $\mathrm{ESA}_{\mathrm{A}}=5.79 \mathrm{E}+5-\mathrm{cm}^{2} /$ cask $]$,

$\mathrm{P} \quad$ is the depth of corrosion attack [5.E-04-cm],

$\mathrm{T}_{\mathrm{F}} \quad$ is the oxide spallation fraction $\left[\mathrm{T}_{\mathrm{F}, \mathrm{N}}=0.15, \mathrm{~T}_{\mathrm{F}, \mathrm{A}}=1.0\right]$

$\mathrm{V}_{\mathrm{M}}$ is the volume of the meat region of the fuel per cask [1.62E $+4-\mathrm{cm}^{3} / \mathrm{cask}$ ], and

$\mathrm{V}_{\mathrm{C}}$ is the free volume of the cask $\left[2.293 \mathrm{E}+5-\mathrm{cm}^{3}\right]$.

The releasable activity density inside the containment vessel due to the release of fines is thus:

$$
\begin{aligned}
& \mathrm{C}_{\text {fines }, \mathrm{N}}=(2.96 \mathrm{E}+4 \cdot 9.06 \mathrm{E}+4 \cdot 5 \mathrm{E}-4 \cdot 0.15 / 1.62 \mathrm{E}+4) \cdot(1 / 2.293 \mathrm{E}+5)=5.41 \mathrm{E}-5 \mathrm{Ci} / \mathrm{cm}^{3} \\
& \mathrm{C}_{\text {fines }, \mathrm{A}}=(2.96 \mathrm{E}+4 \cdot 5.79 \mathrm{E}+5 \cdot 5 \mathrm{E}-4 \cdot 1.0 / 1.62 \mathrm{E}+4) \cdot(1 / 2.293 \mathrm{E}+5)=2.30 \mathrm{E}-3 \mathrm{Ci} / \mathrm{cm}^{3}
\end{aligned}
$$




\section{A.2.4 Activity Density of Crud}

The releasable activity density inside the containment vessel due to the release of crud is described by:

$$
\mathrm{C}_{\text {crud }}=\left(\mathrm{f}_{\mathrm{C}} \cdot \mathrm{S}_{\mathrm{C}} \cdot \mathrm{S}_{\mathrm{A}}\right) / \mathrm{V}_{\mathrm{C}}
$$

where:

$\mathrm{f}_{\mathrm{C}} \quad$ is the crud spallation fraction $\left[\mathrm{f}_{\mathrm{C}, \mathrm{N}}=0.15, \mathrm{f}_{\mathrm{C}, \mathrm{A}}=1.0\right]$,

$\mathrm{S}_{\mathrm{C}} \quad$ is the crud surface activity $\left[1.39 \mathrm{E}-7 \mathrm{Ci} / \mathrm{cm}^{2}\right]$,

$\mathrm{S}_{\mathrm{A}}$ is the sum of the surface areas of all assemblies $\left[9.44 \mathrm{E}+5-\mathrm{cm}^{2}\right]$, and

$\mathrm{V}_{\mathrm{C}}$ is the free volume of the cask $\left[2.293 \mathrm{E}+5-\mathrm{cm}^{3}\right]$.

The releasable activity density inside the containment vessel due to the release of crud is thus:

$$
\begin{aligned}
& \mathrm{C}_{\text {crud }, \mathrm{N}}=(0.15 \cdot 1.39 \mathrm{E}-7 \cdot 9.44 \mathrm{E}+5) / 2.293 \mathrm{E}+5=8.59 \mathrm{E}-8 \\
& \mathrm{C}_{\text {crud }, \mathrm{A}}=(1.0 \cdot 1.39 \mathrm{E}-7 \cdot 9.44 \mathrm{E}+5) / 2.293 \mathrm{E}+5=5.72 \mathrm{E}-7
\end{aligned}
$$

\section{A.3 Determining the Volumetric Leakage Rate at Standard Conditions}

Due to the difference in the assumptions for exposed meat surface area, the remainder of the containment calculations to ultimately determine the volumetric leakage rate at the standard conditions must be treated separately.

\section{A.3.1 Combining the Sources of Radioactive Material in the Cask Free Volume}

The following sections present the calculations for determining the activity density and group $\mathrm{A}_{2}$ values for the radioactive materials released to the free volume of the cask for the three cases.

\section{A.3.1.1 Activity Density and Group A 2 for the Best Estimate Case}

The contributions to the total activity density in the shipping cask free volume from the four sources are combined by:

$$
\mathrm{C}_{\text {total }}=\mathrm{C}_{\text {gas }}+\mathrm{C}_{\mathrm{vol}}+\mathrm{C}_{\text {fines }}+\mathrm{C}_{\text {crud }}
$$

The total releasable activity density inside the containment vessel due to the release of gases, volatiles, fines, and crud is thus:

$$
\begin{aligned}
& \mathrm{C}_{\text {total }, \mathrm{N}}=\mathrm{C}_{\mathrm{N}}=6.57 \mathrm{E}-4+5.95 \mathrm{E}-8+7.52 \mathrm{E}-8+8.59 \mathrm{E}-8=6.57 \mathrm{E}-4 \mathrm{Ci} / \mathrm{cm}^{3} \\
& \mathrm{C}_{\text {total }, \mathrm{A}}=\mathrm{C}_{\mathrm{A}}=2.19 \mathrm{E}-3+5.95 \mathrm{E}-8+1.00 \mathrm{E}-6+5.72 \mathrm{E}-7=2.19 \mathrm{E}-3 \mathrm{Ci} / \mathrm{cm}^{3}
\end{aligned}
$$

The mixture $\mathrm{A}_{2}$ values derived previously are combined to determine a group $\mathrm{A}_{2}$ for normal and accident conditions of transport, respectively, using the following equation.

$$
\mathrm{A}_{2}=\left(\sum\left(\mathrm{F}_{\mathrm{i}} / \mathrm{A}_{2 \mathrm{i}}\right)\right)^{-1},
$$


where:

$\mathrm{F}_{\mathrm{i}}$ is the fraction activity density of contributor $i$ (i.e., gas, volatiles, fines, or crud) in the mixture and

$\mathrm{A}_{2 \mathrm{i}} \quad$ is the appropriate $\mathrm{A}_{2}$ value for mixture $i$.

The group $\mathrm{A}_{2}$ value is calculated in the following tables for normal and accident conditions.

Table A.4 Normal Conditions of Transport

\begin{tabular}{|c|c|c|c|c|}
\hline Source & $\begin{array}{c}\mathrm{A}_{2}-\mathrm{Value} \\
{[\mathrm{Ci}]} \\
\mathrm{A}_{2 i}\end{array}$ & $\begin{array}{c}\text { Concentration } \\
{\left[\mathrm{Ci} / \mathrm{cm}^{3}\right]} \\
\mathrm{C}_{\mathrm{i}}\end{array}$ & $\begin{array}{c}\text { Fraction } \\
\text { [Fr] } \\
\mathbf{F}_{i}=\mathbf{C}_{i} / \Sigma \mathbf{C}_{\mathbf{i}}\end{array}$ & $\begin{array}{c}\mathbf{F r} / \mathrm{A}_{2} \\
{[1 / \mathrm{Ci}]} \\
\mathrm{F}_{i} / \mathrm{A}_{2 i}\end{array}$ \\
\hline Gas & $2.7798 \mathrm{E}+02$ & $6.5706 \mathrm{E}-04$ & $9.9966 \mathrm{E}-01$ & $3.5962 \mathrm{E}-03$ \\
\hline Volatiles & $4.6788 \mathrm{E}+00$ & $5.9456 \mathrm{E}-08$ & $9.0458 \mathrm{E}-05$ & $1.9334 \mathrm{E}-05$ \\
\hline Fines & $2.4838 \mathrm{E}-01$ & $7.5184 \mathrm{E}-08$ & $1.1439 \mathrm{E}-04$ & $4.6054 \mathrm{E}-04$ \\
\hline Crud & $2.6990 \mathrm{E}-01$ & $8.5857 \mathrm{E}-08$ & $1.3062 \mathrm{E}-04$ & $4.8398 \mathrm{E}-04$ \\
\hline \multirow[t]{2}{*}{ Sum Totals: } & \multicolumn{2}{|c|}{$\Sigma \mathbf{C}_{\mathbf{i}}=6.5728 \mathrm{E}-04$} & \multicolumn{2}{|c|}{$\Sigma\left(\mathbf{F}_{i} / \mathbf{A}_{2 i}\right)=4.5601 \mathrm{E}-03$} \\
\hline & & & Group $A_{2}$ & $=2.1929 \mathrm{E}+02 \mathbf{C i}$ \\
\hline
\end{tabular}

Table A.5 Accident Conditions of Transport

\begin{tabular}{|c|c|c|c|c|}
\hline Source & $\begin{array}{c}\mathbf{A}_{2}-\mathrm{Value} \\
{[\mathrm{Ci}]} \\
\mathbf{A}_{2 i}\end{array}$ & $\begin{array}{c}\text { Concentration } \\
{\left[\mathrm{Ci} / \mathrm{cm}^{3}\right]} \\
\mathrm{C}_{i}\end{array}$ & $\begin{array}{c}\text { Fraction } \\
{[\text { Fr] }} \\
\mathbf{F}_{i}=\mathbf{C}_{i} / \Sigma \mathbf{C}_{i}\end{array}$ & $\begin{array}{c}\mathbf{F r} / \mathbf{A}_{2} \\
{[1 / \mathrm{Ci}]} \\
\mathbf{F}_{i} / \mathbf{A}_{2 i}\end{array}$ \\
\hline Gas & $2.7798 \mathrm{E}+02$ & $2.1902 \mathrm{E}-03$ & $9.9925 \mathrm{E}-01$ & $3.5948 \mathrm{E}-03$ \\
\hline Volatiles & $4.6788 \mathrm{E}+00$ & $5.9456 \mathrm{E}-08$ & $2.7126 \mathrm{E}-05$ & $5.7977 \mathrm{E}-06$ \\
\hline Fines & $2.4838 \mathrm{E}-01$ & $1.0025 \mathrm{E}-06$ & $4.5736 \mathrm{E}-04$ & $1.8414 \mathrm{E}-03$ \\
\hline Crud & $2.6990 E-01$ & $5.7238 \mathrm{E}-07$ & $2.6114 \mathrm{E}-04$ & $9.6755 \mathrm{E}-04$ \\
\hline \multirow[t]{2}{*}{ Sum Totals: } & \multicolumn{2}{|c|}{$\Sigma \mathbf{C}_{\mathbf{i}}=2.1918 \mathrm{E}-03$} & \multicolumn{2}{|c|}{$\Sigma\left(\mathbf{F}_{i} / \mathbf{A}_{\mathbf{2 i}}\right)=6.4095 \mathrm{E}-03$} \\
\hline & & & Group $A_{2}$ & $=1.5602 \mathrm{E}+02 \mathrm{Ci}$ \\
\hline
\end{tabular}

\section{A.3.1.2 Activity Density and Group $A_{2}$ for the Conservative Estimate Case}

The contributions to the total activity density in the shipping cask free volume from the four sources are combined by:

$$
\mathrm{C}_{\text {total }}=\mathrm{C}_{\mathrm{gas}}+\mathrm{C}_{\mathrm{vol}}+\mathrm{C}_{\text {fines }}+\mathrm{C}_{\text {crud }} \text {, }
$$

The total releasable activity density inside the containment vessel due to the release of gases, volatiles, fines, and crud is thus:

$$
\begin{aligned}
& \mathrm{C}_{\text {total, } \mathrm{N}}=\mathrm{C}_{\mathrm{N}}=6.57 \mathrm{E}-4+5.95 \mathrm{E}-8+1.43 \mathrm{E}-6+8.59 \mathrm{E}-8=6.59 \mathrm{E}-4 \mathrm{Ci} / \mathrm{cm}^{3} \\
& \mathrm{C}_{\text {total }, \mathrm{A}}=\mathrm{C}_{\mathrm{A}}=2.19 \mathrm{E}-3+5.95 \mathrm{E}-8+1.90 \mathrm{E}-5+5.72 \mathrm{E}-7=2.21 \mathrm{E}-3 \mathrm{Ci} / \mathrm{cm}^{3}
\end{aligned}
$$

The mixture $\mathrm{A}_{2}$ values derived previously are combined to determine a group $\mathrm{A}_{2}$ for normal and accident conditions of transport, respectively, using the following equation.

$$
\mathrm{A}_{2}=\left(\sum\left(\mathrm{F}_{\mathrm{i}} / \mathrm{A}_{2 \mathrm{i}}\right)\right)^{-1}
$$


where:

$\mathrm{F}_{\mathrm{i}} \quad$ is the fraction activity density of contributor $i$ (i.e., gas, volatiles, fines, or crud) in the mixture and

$\mathrm{A}_{2 \mathrm{i}}$ is the appropriate $\mathrm{A}_{2}$ value for mixture $i$.

The group $\mathrm{A}_{2}$ value is calculated in the following tables for normal and accident conditions.

Table A.6 Normal Conditions of Transport

\begin{tabular}{|c|c|c|c|c|}
\hline Source & $\begin{array}{c}\mathrm{A}_{2}-\mathrm{Value} \\
{[\mathrm{Ci}]} \\
\mathrm{A}_{2 i}\end{array}$ & $\begin{array}{c}\text { Concentration } \\
{\left[\mathrm{Ci} / \mathrm{cm}^{3}\right]} \\
\mathrm{C}_{\mathrm{i}}\end{array}$ & $\begin{array}{c}\text { Fraction } \\
\text { [Fr] } \\
\mathbf{F}_{i}=\mathbf{C}_{i} / \Sigma \mathbf{C}_{\mathbf{i}}\end{array}$ & $\begin{array}{c}\mathbf{F r} / \mathrm{A}_{2} \\
{[1 / \mathrm{Ci}]} \\
\mathrm{F}_{\mathrm{i}} / \mathrm{A}_{2 i}\end{array}$ \\
\hline Gas & $2.7798 \mathrm{E}+02$ & $6.5706 \mathrm{E}-04$ & $9.9761 \mathrm{E}-01$ & $3.5888 \mathrm{E}-03$ \\
\hline Volatiles & $4.6788 \mathrm{E}+00$ & $5.9456 \mathrm{E}-08$ & $9.0272 \mathrm{E}-05$ & $1.9294 \mathrm{E}-05$ \\
\hline Fines & $2.4838 \mathrm{E}-01$ & $1.4285 \mathrm{E}-06$ & $2.1689 \mathrm{E}-03$ & $8.7322 \mathrm{E}-03$ \\
\hline Crud & $2.6990 \mathrm{E}-01$ & $8.5857 \mathrm{E}-08$ & $1.3036 \mathrm{E}-04$ & $4.8298 \mathrm{E}-04$ \\
\hline \multirow[t]{2}{*}{ Sum Totals: } & \multicolumn{2}{|c|}{$\Sigma \mathbf{C}_{\mathbf{i}}=6.5863 \mathrm{E}-04$} & \multicolumn{2}{|c|}{$\Sigma\left(\mathbf{F}_{i} / \mathbf{A}_{\mathbf{2}_{i}}\right)=1.2823 \mathrm{E}-02$} \\
\hline & & & Group $A_{2}$ & $=7.7983 \mathrm{E}+01 \mathbf{C i}$ \\
\hline
\end{tabular}

Table A.7 Accident Conditions of Transport

\begin{tabular}{|c|c|c|c|c|}
\hline Source & $\begin{array}{c}\mathbf{A}_{2}-\mathrm{Value} \\
{[\mathrm{Ci}]} \\
\mathbf{A}_{2 i}\end{array}$ & $\begin{array}{c}\text { Concentration } \\
{\left[\mathrm{Ci} / \mathrm{cm}^{3}\right]} \\
\mathrm{C}_{\mathrm{i}}\end{array}$ & $\begin{array}{c}\text { Fraction } \\
{[\text { Fr] }} \\
\mathbf{F}_{i}=\mathbf{C}_{i} / \Sigma \mathbf{C}_{i}\end{array}$ & $\begin{array}{c}\mathbf{F r} / \mathbf{A}_{2} \\
{[1 / \mathrm{Ci}]} \\
\mathbf{F}_{i} / \mathbf{A}_{2 i}\end{array}$ \\
\hline Gas & $2.7798 \mathrm{E}+02$ & $2.1902 \mathrm{E}-03$ & $9.9110 \mathrm{E}-01$ & $3.5654 \mathrm{E}-03$ \\
\hline Volatiles & $4.6788 \mathrm{E}+00$ & $5.9456 \mathrm{E}-08$ & $2.6905 \mathrm{E}-05$ & $5.7504 \mathrm{E}-06$ \\
\hline Fines & $2.4838 \mathrm{E}-01$ & $1.9047 \mathrm{E}-05$ & $8.6189 \mathrm{E}-03$ & $3.4701 \mathrm{E}-02$ \\
\hline Crud & $2.6990 E-01$ & $5.7238 \mathrm{E}-07$ & $2.5901 \mathrm{E}-04$ & $9.5965 \mathrm{E}-04$ \\
\hline \multirow[t]{2}{*}{ Sum Totals: } & \multicolumn{2}{|c|}{$\Sigma \mathbf{C}_{\mathbf{i}}=2.2099 \mathrm{E}-03$} & \multicolumn{2}{|c|}{$\Sigma\left(\mathbf{F}_{\mathbf{i}} / \mathbf{A}_{\mathbf{2 i}}\right)=3.9232 \mathrm{E}-02$} \\
\hline & & & Group $A_{2}$ & $=2.5490 \mathrm{E}+01 \mathbf{C i}$ \\
\hline
\end{tabular}

\section{A.3.1.3 Activity Density and Group $A_{2}$ for the Bounding Case}

The total releasable activity density inside the containment vessel due to the release of gases, volatiles, fines, and crud is thus:

$$
\begin{aligned}
& \mathrm{C}_{\text {total }, \mathrm{N}}=\mathrm{C}_{\mathrm{N}}=6.57 \mathrm{E}-4+5.95 \mathrm{E}-8+5.41 \mathrm{E}-5+8.59 \mathrm{E}-8=7.11 \mathrm{E}-4 \mathrm{Ci} / \mathrm{cm}^{3} \\
& \mathrm{C}_{\text {total }, \mathrm{A}}=\mathrm{C}_{\mathrm{A}}=2.19 \mathrm{E}-3+5.95 \mathrm{E}-8+2.30 \mathrm{E}-3+5.72 \mathrm{E}-7=4.49 \mathrm{E}-3 \mathrm{Ci} / \mathrm{cm}^{3}
\end{aligned}
$$

The group $\mathrm{A}_{2}$ value is calculated in the following tables for normal and accident conditions, respectively. 
Table A.8 Normal Conditions of Transport

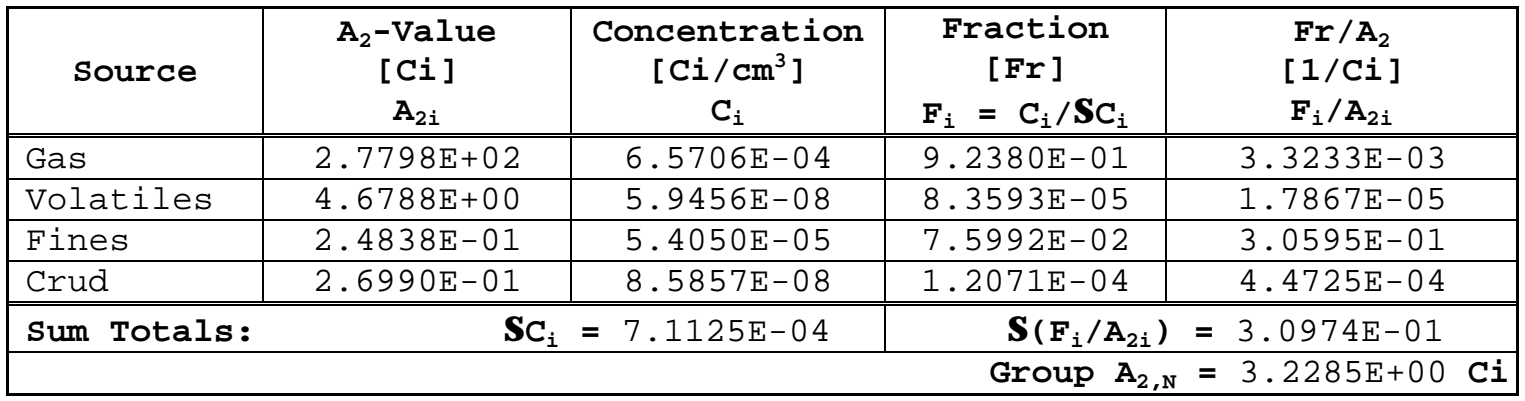

Table A.9 Accident Conditions of Transport

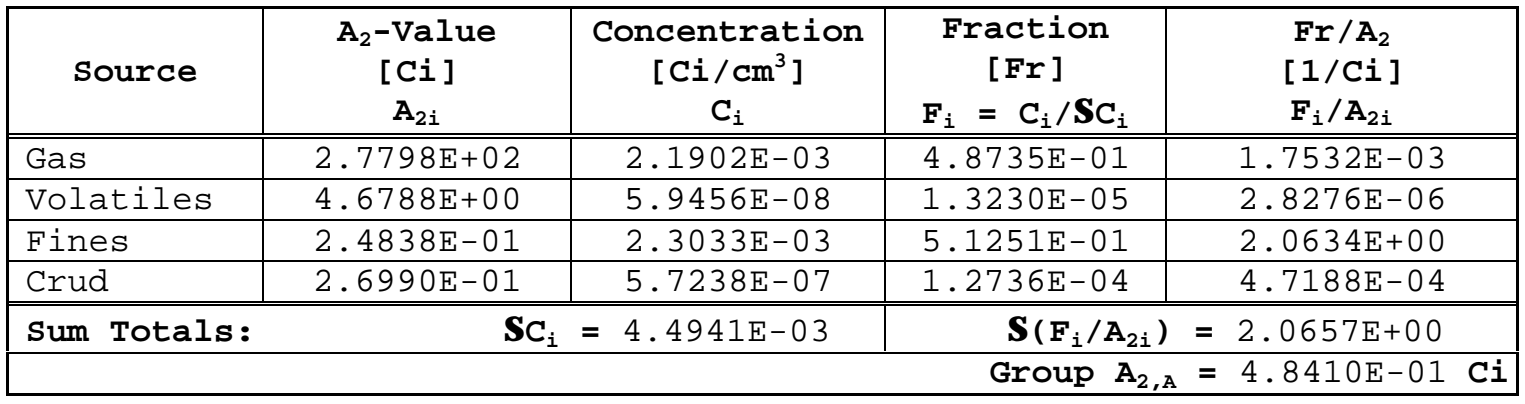

\section{A.3.2 Maximum Permissible Release Rate and Maximum Permissible Leakage Rate}

The following sections present the calculations for determining the maximum permissible release rate and maximum permissible leakage rate for the radioactive materials released to the free volume of the cask for the three cases.

\section{A.3.2.1 Maximum Permissible Release Rate and Maximum Permissible Leakage Rate for the Best Estimate Case}

Assuming that the release rate is independent of time, the maximum permissible release rates for normal and accident conditions of transport, respectively, can be expressed as follows:

$$
\begin{aligned}
& \mathrm{R}_{\mathrm{N}}=\mathrm{A}_{2, \mathrm{~N}} \times 2.78 \times 10^{-10} / \text { second, } \\
& \mathrm{R}_{\mathrm{A}}=\mathrm{A}_{2, \mathrm{~A}} \times 1.65 \times 10^{-6} / \text { second, }
\end{aligned}
$$

The maximum permissible release rate for normal and accident conditions of transport are thus:

$$
\begin{aligned}
& \mathrm{R}_{\mathrm{N}}=219.3 \times 2.78 \times 10^{-10}=6.10 \mathrm{E}-8 \mathrm{Ci} / \mathrm{s} \\
& \mathrm{R}_{\mathrm{A}}=156.0 \times 1.65 \times 10^{-6}=2.57 \mathrm{E}-4 \mathrm{Ci} / \mathrm{s}
\end{aligned}
$$

The maximum permissible leakage rate is given by:

$$
\begin{aligned}
& \mathrm{L}_{\mathrm{N}}=\mathrm{R}_{\mathrm{N}} / \mathrm{C}_{\mathrm{N}}, \\
& \mathrm{L}_{\mathrm{A}}=\mathrm{R}_{\mathrm{A}} / \mathrm{C}_{\mathrm{A}},
\end{aligned}
$$


Substitution of the appropriate values into the previous equation gives:

$$
\begin{aligned}
& \mathrm{L}_{\mathrm{N}}=6.10 \mathrm{E}-8 / 6.57 \mathrm{E}-4=9.28 \mathrm{E}-5 \mathrm{~cm}^{3} / \mathrm{s} \\
& \mathrm{L}_{\mathrm{A}}=2.57 \mathrm{E}-4 / 2.19 \mathrm{E}-3=1.18 \mathrm{E}-1 \mathrm{~cm}^{3} / \mathrm{s}
\end{aligned}
$$

\section{A.3.2.2 Maximum Permissible Release Rate and Maximum Permissible Leakage Rate for the Conservative Estimate Case}

Assuming that the release rate is independent of time, the maximum permissible release rates for normal and accident conditions of transport, respectively, can be expressed as follows:

$$
\begin{aligned}
& \mathrm{R}_{\mathrm{N}}=\mathrm{A}_{2, \mathrm{~N}} \times 2.78 \times 10^{-10} / \text { second, } \\
& \mathrm{R}_{\mathrm{A}}=\mathrm{A}_{2, \mathrm{~A}} \times 1.65 \times 10^{-6} / \text { second, }
\end{aligned}
$$

The maximum permissible release rate for normal and accident conditions of transport are thus:

$$
\begin{aligned}
& \mathrm{R}_{\mathrm{N}}=78.0 \times 2.78 \times 10^{-10}=2.17 \mathrm{E}-8 \mathrm{Ci} / \mathrm{s} \\
& \mathrm{R}_{\mathrm{A}}=25.5 \times 1.65 \times 10^{-6}=4.21 \mathrm{E}-5 \mathrm{Ci} / \mathrm{s}
\end{aligned}
$$

The maximum permissible leakage rate is given by:

$$
\begin{aligned}
& \mathrm{L}_{\mathrm{N}}=\mathrm{R}_{\mathrm{N}} / \mathrm{C}_{\mathrm{N}}, \\
& \mathrm{L}_{\mathrm{A}}=\mathrm{R}_{\mathrm{A}} / \mathrm{C}_{\mathrm{A}},
\end{aligned}
$$

Substitution of the appropriate values into the previous equation gives:

$$
\begin{aligned}
& \mathrm{L}_{\mathrm{N}}=2.17 \mathrm{E}-8 / 6.59 \mathrm{E}-4=3.29 \mathrm{E}-5 \mathrm{~cm}^{3} / \mathrm{s} \\
& \mathrm{L}_{\mathrm{A}}=4.21 \mathrm{E}-5 / 2.21 \mathrm{E}-3=1.90 \mathrm{E}-2 \mathrm{~cm}^{3} / \mathrm{s}
\end{aligned}
$$

\section{A.3.2.3 Maximum Permissible Release Rate and Maximum Permissible Leakage Rate for the Bounding Case}

Assuming that the release rate is independent of time, the maximum permissible release rates for normal and accident conditions of transport, respectively, are as follows:

$$
\begin{aligned}
& \mathrm{R}_{\mathrm{N}}=3.23 \times 2.78 \times 10^{-10}=8.98 \mathrm{E}-10 \mathrm{Ci} / \mathrm{s} \\
& \mathrm{R}_{\mathrm{A}}=0.48 \times 1.65 \times 10^{-6}=7.99 \mathrm{E}-7 \mathrm{Ci} / \mathrm{s}
\end{aligned}
$$

The maximum permissible leakage rate is calculated as follows:

$$
\begin{aligned}
& \mathrm{L}_{\mathrm{N}}=8.98 \mathrm{E}-10 / 7.11 \mathrm{E}-4=1.26 \mathrm{E}-6 \mathrm{~cm}^{3} / \mathrm{s} \\
& \mathrm{L}_{\mathrm{A}}=7.99 \mathrm{E}-7 / 4.49 \mathrm{E}-3=1.78 \mathrm{E}-4 \mathrm{~cm}^{3} / \mathrm{s}
\end{aligned}
$$

\section{A.3.3 Permissible Leak Rate at Standard Conditions}

The following sections present the calculations for determining the permissible leak rate at standard condition for the radioactive materials released to the free volume of the cask for the three cases. 
The volumetric gas leak rate is modeled as a combination of continuum and molecular flow through a single leak path. The leak path is modeled as a smooth, right-circular cylinder with sharp edges. Based on these assumptions, the equation for gas leaking from the cask takes the following form.

$\mathrm{L}=\mathrm{L}_{\mathrm{c}}+\mathrm{L}_{\mathrm{m}}$

where:

$\mathrm{L}$ is the total volumetric gas flow rate at $\mathrm{P}_{\mathrm{u}}\left[\mathrm{cm}^{3} / \mathrm{sec}\right]$,

$\mathrm{L}_{\mathrm{c}}$ is the volumetric flow rate due to continuum flow $\left[\mathrm{cm}^{3} / \mathrm{sec}\right]$, and

$\mathrm{L}_{\mathrm{m}}$ is the volumetric flow rate due to molecular flow $\left[\mathrm{cm}^{3} / \mathrm{sec}\right]$.

The volumetric flow rate, $\mathrm{L}_{\mathrm{c}}$, for continuum flow is given by

$$
\mathrm{L}_{\mathrm{c}}=\left[\left(2.49 \times 10^{6} \mathrm{D}^{4}\right) / \mathrm{a} \mu\right] \cdot\left(\mathrm{P}_{\mathrm{u}}-\mathrm{P}_{\mathrm{d}}\right)\left(\mathrm{P}_{\mathrm{a}} / \mathrm{P}_{\mathrm{u}}\right)
$$

where:

$\mathrm{L}_{\mathrm{c}}$ is the volumetric flow rate due to continuum flow $\left[\mathrm{cm}^{3} / \mathrm{sec}\right]$,

$\mathrm{D}$ is the capillary diameter $[\mathrm{cm}]$,

a is the capillary length [1-cm],

$\mu \quad$ is the fluid viscosity [NTC/ATC $=0.02736-\mathrm{cP} / 0.03129-\mathrm{cP}$ ],

$\mathrm{P}_{\mathrm{u}} \quad$ is the upstream pressure [NTC/ATC $=1.99$-atm/11.4-atm],

$\mathrm{P}_{\mathrm{d}} \quad$ is the downstream pressure [1-atm], and

$\mathrm{P}_{\mathrm{a}}$ is the average pressure, $\left(\mathrm{P}_{\mathrm{u}}-\mathrm{P}_{\mathrm{d}}\right) / 2$ [NTC/ATC $=1.495$-atm/6.2-atm].

The volumetric flow rate, $\mathrm{L}_{\mathrm{m}}$, for molecular flow is given by

$$
\mathrm{L}_{\mathrm{m}}=\left[\left(3.81 \times 10^{3} \mathrm{D}^{3}(\mathrm{~T} / \mathrm{M})^{0.5}\right) / \mathrm{aP} \mathrm{a}\right] \cdot\left(\mathrm{P}_{\mathrm{u}}-\mathrm{P}_{\mathrm{d}}\right)\left(\mathrm{P}_{\mathrm{a}} / \mathrm{P}_{\mathrm{u}}\right),
$$

where:

$\mathrm{L}_{\mathrm{m}}$ is the volumetric flow rate due to molecular flow $\left[\mathrm{cm}^{3} / \mathrm{sec}\right.$,

$\mathrm{D}$ is the capillary diameter [cm],

$\mathrm{T}$ is the gas temperature [NTC/ATC $=474-\mathrm{K} / 574-\mathrm{K}$ ],

$\mathrm{M}$ is the gas molecular weight [4-g/mole],

a is the capillary length $[1-\mathrm{cm}]$,

$\mathrm{P}_{\mathrm{a}}$ is the average pressure, $\left(\mathrm{P}_{\mathrm{u}}-\mathrm{P}_{\mathrm{d}}\right) / 2$ [NTC/ATC $=1.495$-atm/6.2-atm],

$\mathrm{P}_{\mathrm{u}}$ is the upstream pressure [NTC/ATC $=1.99$-atm/11.4-atm], and

$\mathrm{P}_{\mathrm{d}} \quad$ is the downstream pressure [1-atm].

The volumetric gas flow rates at the upstream pressure for normal transport conditions, $\mathrm{L}_{\mathrm{N}}$, and accident transport conditions, $\mathrm{L}_{\mathrm{A}}$, respectively, are therefore given by the following:

$$
\begin{aligned}
\mathrm{L}_{\mathrm{N}}=\left\{\left(2.49 \times 10^{6} \cdot \mathrm{D}^{4}\right) /(1 \bullet 0.02736)+\left(3.81 \times 10^{3} \cdot \mathrm{D}^{3}(474 / 4)^{0.5}\right) /(1 \bullet 1.495)\right\} \bullet & \\
& (1.99-1)(1.495 / 1.99) \\
\mathrm{L}_{\mathrm{N}}=\{ & \left\{9.10 \mathrm{E}+7 \cdot \mathrm{D}^{4}+2.77 \mathrm{E}+4 \cdot \mathrm{D}^{3}\right\}(0.74) \\
\mathrm{L}_{\mathrm{N}}= & 6.73 \mathrm{E}+7 \cdot \mathrm{D}^{4}+2.05 \mathrm{E}+4 \cdot \mathrm{D}^{3}
\end{aligned}
$$




$$
\begin{aligned}
\mathrm{L}_{\mathrm{A}}=\{( & \left.\left(2.49 \times 10^{6} \cdot \mathrm{D}^{4}\right) /(1 \bullet 0.03129)+\left(3.81 \times 10^{3} \cdot \mathrm{D}^{3}(574 / 4)^{0.5}\right) /(1 \cdot 6.2)\right\} \bullet \\
& (11.4-1)(6.2 / 11.4) \\
\mathrm{L}_{\mathrm{A}}=\{ & \left(7.96 \mathrm{E}+7 \cdot \mathrm{D}^{4}+7.36 \mathrm{E}+3 \cdot \mathrm{D}^{3}\right\}(5.66) \\
\mathrm{L}_{\mathrm{A}}= & 4.50 \mathrm{E}+8 \cdot \mathrm{D}^{4}+4.16 \mathrm{E}+4 \cdot \mathrm{D}^{3}
\end{aligned}
$$

Substituting the appropriate values for $\mathrm{L}_{\mathrm{N}}$ and $\mathrm{L}_{\mathrm{A}}$ in equations 1 and 2 allows the determination of the capillary diameter for leakage. The resulting diameter value is used in the following equations to correlate the maximum permissible leak rate given by equations 1 and 2 to the leak rate at standard temperature and pressure. Details of these calculations are presented in Table A.10.

$$
\begin{aligned}
& \mathrm{L}_{\mathrm{R}, \mathrm{N}}=\mathrm{L}_{\mathrm{c}}+\mathrm{L}_{\mathrm{m}}=\left\{\left(2.49 \times 10^{6} \mathrm{D}^{4}\right) / \mathrm{a} \mu+\left(3.81 \times 10^{3} \mathrm{D}^{3}(\mathrm{~T} / \mathrm{M})^{0.5}\right) / \mathrm{aP}\right\} \cdot\left(\mathrm{P}_{\mathrm{u}}-\mathrm{P}_{\mathrm{d}}\right)\left(\mathrm{P}_{\mathrm{a}} / \mathrm{P}_{\mathrm{u}}\right), \\
& \mathrm{L}_{\mathrm{R}, \mathrm{A}}=\mathrm{L}_{\mathrm{c}}+\mathrm{L}_{\mathrm{m}}=\left\{\left(2.49 \times 10^{6} \mathrm{D}^{4}\right) / \mathrm{a} \mu+\left(3.81 \times 10^{3} \mathrm{D}^{3}(\mathrm{~T} / \mathrm{M})^{0.5}\right) / \mathrm{aP}\right\} \cdot\left(\mathrm{P}_{\mathrm{u}}-\mathrm{P}_{\mathrm{d}}\right)\left(\mathrm{P}_{\mathrm{a}} / \mathrm{P}_{\mathrm{u}}\right),
\end{aligned}
$$

where:

$\mathrm{L}_{\mathrm{R}, \mathrm{N}}$ is the volumetric leakage rate at standard conditions correlating to normal conditions of transport $\left[\mathrm{cm}^{3} / \mathrm{sec}\right]$,

$\mathrm{L}_{\mathrm{R}, \mathrm{A}}$ is the volumetric leakage rate at standard conditions correlating to accident conditions of transport $\left[\mathrm{cm}^{3} / \mathrm{sec}\right]$,

$\mathrm{L}_{\mathrm{c}}$ is the volumetric flow rate due to continuum flow [ $\mathrm{cm}^{3} / \mathrm{sec}$,

$\mathrm{L}_{\mathrm{m}}$ is the volumetric flow rate due to molecular flow $\left[\mathrm{cm}^{3} / \mathrm{sec}\right]$,

D is the capillary diameter [determined through application of Eqs. 1 \& 2],

a is the capillary length [1-cm],

$\mu \quad$ is the fluid viscosity [0.018494-cP],

$\mathrm{P}_{\mathrm{u}} \quad$ is the upstream pressure [1-atm],

$\mathrm{P}_{\mathrm{d}} \quad$ is the downstream pressure [0.01-atm],

$\mathrm{P}_{\mathrm{a}} \quad$ is the average pressure, $\left(\mathrm{P}_{\mathrm{u}}-\mathrm{P}_{\mathrm{d}}\right) / 2[0.505$-atm],

$\mathrm{T}$ is the gas temperature [298-K], and

$\mathrm{M}$ is the gas molecular weight [29-g/mole].

Table A.10 Calculations of Maximum Permissible Leak Rate at Standard Conditions

\begin{tabular}{|l|c|c|c|c|c|c|}
\hline \multirow{2}{*}{ Parameter } & \multicolumn{2}{|c|}{ Best Estimate } & \multicolumn{2}{c|}{$\begin{array}{c}\text { Conservative } \\
\text { Estimate }\end{array}$} & \multicolumn{2}{c|}{ Bounding Estimate } \\
\cline { 2 - 7 } & $\begin{array}{c}\text { Normal } \\
\text { Transport } \\
\text { Conditions }\end{array}$ & $\begin{array}{c}\text { Accident } \\
\text { Transport } \\
\text { Conditions }\end{array}$ & $\begin{array}{c}\text { Normal } \\
\text { Transport } \\
\text { Conditions }\end{array}$ & $\begin{array}{c}\text { Accident } \\
\text { Transport } \\
\text { Conditions }\end{array}$ & $\begin{array}{c}\text { Normal } \\
\text { Transport } \\
\text { Conditions }\end{array}$ & $\begin{array}{c}\text { Accident } \\
\text { Transport } \\
\text { Conditions }\end{array}$ \\
\hline $\begin{array}{l}\text { Maximum Permissible } \\
\text { Leakage Rate }(\mathbf{L})\left[\mathbf{c m}^{3} / \mathbf{s}\right]\end{array}$ & $9.28 \mathrm{E}-5$ & $1.17 \mathrm{E}-1$ & $3.29 \mathrm{E}-5$ & $1.90 \mathrm{E}-2$ & $1.26 \mathrm{E}-6$ & $1.78 \mathrm{E}-4$ \\
\hline Capillary Diameter $(\mathbf{D})[\mathbf{c m}]$ & $1.013 \mathrm{E}-3$ & $3.996 \mathrm{E}-3$ & $7.681 \mathrm{E}-4$ & $2.527 \mathrm{E}-3$ & $3.116 \mathrm{E}-4$ & $7.705 \mathrm{E}-4$ \\
\hline $\begin{array}{l}\text { Maximum Permissible } \\
\text { Leakage Rate at Standard } \\
\text { Conditions }\left(\mathbf{L}_{\mathbf{R}}\right)\left[\mathbf{c m}^{\mathbf{3}} / \mathbf{s}\right]\end{array}$ & $\mathbf{8 . 3 5 E - 5}$ & $\mathbf{1 . 7 9 E - 2}$ & $\mathbf{2 . 8 9 E - 5}$ & $\mathbf{2 . 9 4 E - 3}$ & $\mathbf{1 . 0 0 E - 6}$ & $\mathbf{2 . 9 3 E - 5}$ \\
\hline
\end{tabular}

\section{A.4 Results}

The results indicate that the spent fuel can be transported in the LWT and maintained within the allowable release rates under normal and accident conditions. Comparison of the calculated maximum permissible 
leakage rates at standard conditions to the test leakage rate of the LWT $\left(1.0 \mathrm{E}-6 \mathrm{~cm}^{3} / \mathrm{s}\right)$ indicate that leakage from this cask will not exceed the limit of $\mathrm{A}_{2} \times 10^{-6}$ in one hour and $\mathrm{A}_{2}$ per week under normal and accident transport conditions, respectively. The limiting standard leakage rates for both cases correspond to normal conditions of transport. Therefore, the LWT can safely contain the spent fuel from either case during transport. This result is facilitated by low test leakage rate, low fuel burnup, and long cooling time prior to shipment.

\section{A.5 References}

1 Vinson, D. W., Blanton, P. S., Sindelar, R. L., and Iyer, N. C., "Preliminary Report: Bases for Containment Analysis of Transportation of Aluminum-Based Spent Nuclear Fuel,” WSRC-TR98-00317 (October 1998).

2 “Containment Analysis for Type B Packages Used to Transport Various Contents,” NUREG/CR6487.

3 “Packaging and Transportation of Radioactive Material," Chapter 10, Part 71 of U. S. Code of Federal Regulations.

4 “American National Standard for Radioactive Materials - Leakage Tests on Packages for Shipment,” ANSI N14.5-1997. 
WESTINGHOUSE SAVANNAH RIVER CO. REPORT WSRC-TR-2000-00152 DISTRIBUTION

\section{SAVANNAH RIVER SITE}

W. J. Johnson, 704-C

H. F. Herrera, 704-C

R. J. Skwarek, 704-C

E. R. Conatser, 704-C

S. Wood, 773-A

G. T. Wright, 773-A

C. R. Wolfe, 773-A

N. C. Iyer, 773-41A

M. R. Louthan, Jr., 773-A

G. T. Chandler, 773-A

S. L. West, 773-A

R. L. Bickford, 730-A

C. E. Sessions, 730-A

D. M. Barnes, 707-C

D. W. Bickley, 707-C

T. C. Andes, 707-C

A. S. Busby, 707-C

R. W. Deible, Jr., 707-C

R. L. Sindelar, 773-41A

D. W. Vinson, 773-41A

Site Records, 773-52A 